\title{
Expression Profiles of Subtracted Genes During Neural Differentiation from Human Embryonic Stem Cells using Suppression Subtractive Hybridization
}

\author{
Jung Ki Yoo \\ CHA University \\ Hye Min Noh \\ CHA University \\ Jonghyup Kim \\ Inje University College of Medicine \\ Sehun Lim \\ Inje University College of Medicine \\ Seong-Jun Choi \\ Dankook University \\ Jin Kyeoung Kim ( $\sim$ kyeoung66@hanmail.net ) \\ CHA University
}

\section{Research Article}

Keywords: human embryonic stem cells, neural precursor cells, suppression subtractive hybridization, neural differentiation, differentially expressed genes

Posted Date: October 1st, 2021

DOl: https://doi.org/10.21203/rs.3.rs-933283/v1

License: @ (i) This work is licensed under a Creative Commons Attribution 4.0 International License. Read Full License 


\section{Abstract}

Human embryonic stem cells (human ES cells) are pluripotent and self-renewing cells that can be isolated from the inner cell mass at the blastocyst stage. Human ES cells differentiate into specific cell lineages according to the expression of related genes. During neural development, specific gene expressions induced human ES cells some morphological changes. We used suppression subtractive hybridization to identify genes which shows altered expression during neural differentiation from human ES cells. We identified 90 genes as downregulated and 64 genes as upregulated in neural precursor (NP) cells derived from human ES cells compared with human ES cells. To obtain further information about differentiation, we performed expression profiling of subtracted genes between human ES cells and NP cells. Of the subtracted genes in human ES cells, the 19 genes showed decreased expression in NP cells. Meanwhile, of the subtracted genes in NP cells, the 20 genes were upregulated. Among them, COPZ1, CPSF6, MATR3 and TOMD3 were specific gene expressions that they significantly expressed up and down-regulation during neural development derived from ES cells. These genes have not previously been associated with neural differentiation, but they may be potentially participated in neurogenesis.

\section{Introduction}

Stem cells can self-renew and can differentiate into specific cell types to produce various organs. Stem cells can be subdivided into few groups, such as embryonic stem cells (ES cells), adult stem cells, induced pluripotent stem cells (iPS cells) and somatic cell nuclear transfer ES cells (SCNT-ES cells) (Tachibana et al., 2013). ES cells originate in the inner cell mass of a blastocyst, the stage $5 \sim 7$ days after a human ovum is fertilized. ES cells maintain stemness and specifically express stem cell markers, including Oct4, SSEA-1, SSEA-3, SSEA-4, TRA-1-60, and TRA-1-81, and are pluripotent (Rippon and Bishop, 2004). Research using ES cells comes with ethical issues associated with using donor eggs or pre-implantation embryos (de Wert and Mummery, 2003). On the other hand, adult stem cells can be induced from adult cells, including bone marrow, cord blood, brain, and testis. Adult stem cells also show self-renewal and multidifferentiation but are more limited in both of these functions compared with ES cells (Ramalho-Santos et al., 2002; Yoo et al., 2010). Patient-specific pluripotent stem cells are produced by modifying gene regulation via pluripotency-related genes such as Oct4, Sox2, KIf4 and c-Myc (Takahashi et al., 2007). However, Klf4 and c-Myc have shown tumorigenic potential because these genes activate oncogenic transcription (Evans and Liu, 2008). Therefore, iPS cells are considered unsuitable for use in regenerative medicine. SCNT-ES cells are generated by replacing the nucleus of the host cell with that of a somatic cell, as in the case of Dolly the sheep (Tachibana et al., 2013). This cell type is a good source for patient-specific regenerative medicine applications but has some problems related to donors and ethical issues, similar to those for ES cells (Zacharias et al., 2011). Despite these problems, because stem cells can differentiate into specific tissues or organs, many researchers dedicate time to use in regenerative medicine applications (Zacharias et al., 2011).

During neural differentiation from ES cells, ES cell markers decrease and neural lineage markers such as Nestin and PAX-6 increase in expression (Yap et al., 2015). For the differentiation of NP (neural precursor) cells, most approaches are based on embryoid body (EB) formation. Next, NP cells are generated via differentiation from EBs using various methods (Yap et al., 2015). Recently, NP cells have become an important source for clinical applications of regenerative medicine. The central nervous system (CNS) is not regenerate tissues after birth. Damage to these areas produces CNS disorder (Carpenter et al., 1999). NP cells represent a good source for cell transplantation in therapy for CNS disorders (Wilcox et al., 2014) because NP cells are components of the CNS and show the ability to differentiate into neurons, astrocytes and oligodendrocytes (Goldman, 1995). Although there are known markers of neural differentiation (Yap et al., 2015), they are not strongly expressed specifically in neural cells. In this research, we aimed to identify novel markers of neural differentiation.

PCR based numerous techniques have been used for identification of differentially expressed genes (DEGs), including expressed sequence tag (EST) sequencing, serial analysis of gene expression (SAGE), arbitrary primed-PCR, representational difference analysis (RDA), differential display polymerase chain reaction (DD-PCR) and suppression subtractive hybridization (SSH) (Jung et al., 2009). Benefit of SSH is that it can find novel genes and has a low false-positive rate (Yoo et al., 2010). In our previous study, we reported that the expression of TPX2 gradually decrease during neurogenesis (Noh et al., 2007). Here, we used SSH to identify DEGs during neurogenesis from human ES cells. We then characterized those DEGs and categorized their functions using a bioinformatics approach. Among these genes, specifically expressed genes may be useful as new biomarkers of neural development.

\section{Materials And Methods}

\section{Cell cultureof human ES cells}


The human ES cell line CHA4 was cultivated by using a method described in a previous study (Kim et al., 2007). Human ES cells were cultured on mitotically inactivated STO cells (CRL-1503; ATCC, Manassas, VA, USA) in Dulbecco's modified Eagle's medium (DMEM)/F12 (1:1; Gibco BRL, Gaithersburg, MD, USA) supplemented with $20 \%$ serum replacement (Gibco) and standard human ES cell medium components, including $1 \mathrm{mM} \mathrm{L-glutamine} \mathrm{(Gibco),} \mathrm{1 \%} \mathrm{nonessential} \mathrm{amino} \mathrm{acids} \mathrm{(Gibco),} 100 \mathrm{mM} \beta$-mercaptoethanol (Gibco), and basic fibroblast growth factor (b-FGF, Sigma, USA). The medium was changed every $24 \mathrm{~h}$, and the human ES cells were transferred to new feeder cells every 5-7 days using a dissecting pipette.The CHA4 human ES cell were provided by Stem Cell Research Laboratory of CHA University, respectively

\section{Differentiation of NP cells from human ES cells}

The technique for differentiating NP cellsis described in detail in our previous study(Kim et al., 2004; Noh et al., 2007). Before differentiation of NP cells, human ES cells were induced to form EBs by culturing the ES cells in suspension media withoutbFGF for 20 days. Neuroepithelial cells with a rosette structure appeared after 7 days in culture and were manually isolated from the culture and transferred into new platescontaining F-127 in neurosphere (NS) medium. Neurospheres were formed in suspension culturewithin $24 \mathrm{~h}$ and were subcultured every 14 days. Neurosphere medium consisted of DMEM/F12 (1:1) supplemented with 2 mM L-glutamine, $25 \mu \mathrm{g} / \mathrm{ml}$ human insulin (Sigma, St. Louis, MO, USA), 100 $\mathrm{g} / \mathrm{ml}$ human transferrin (Sigma), $20 \mathrm{nM}$ progesterone (Sigma), $60 \mu \mathrm{M}$ putrescine (Sigma), $30 \mathrm{nM}$ sodium selenite (Sigma), $2 \mu \mathrm{g} / \mathrm{ml}$ heparin (Sigma), recombinant human epidermal growth factor (EGF; R\&D Systems) and $20 \mathrm{ng} / \mathrm{ml} \mathrm{FGF-2.} \mathrm{The} \mathrm{medium} \mathrm{was} \mathrm{changed} \mathrm{every} \mathrm{day} \mathrm{and} \mathrm{characterized} \mathrm{NP} \mathrm{cells} \mathrm{using} \mathrm{RT-PCR} \mathrm{(S1} \mathrm{fig).}$

\section{RNA isolation}

Total RNA was isolated from human ES cells and NP cells using Trizol regent (Life Technology) and quantified using a DN-1000 spectrophotometer (Nanodrop Technologies Inc., Waltham, MA, USA). The $A_{260} / A_{280}$ ratio was in the range of 1.8-2.0. To confirm integrity, approximately $1 \mu \mathrm{g}$ of total RNA was electrophoresed on a $1.2 \%$ denaturing agarose gel.

\section{cDNA synthesis from total RNA}

cDNA was synthesized using the BD SMART ${ }^{\mathrm{TM}}$ CDNA Synthesis Kit (BD Bioscience Clontech, USA) according to the manufacturer's instructions. First-strand cDNA was synthesized from $1 \mu \mathrm{g}$ of total RNA and reverse-transcribed in a $10 \mu$ reaction mixture containing PowerScriptreversetranscriptase (BD Bioscience) using 3' BD SMART CDS primer II A (5'- AAG CAG TGG TAT CAA CGC AGG GTA CTT -3') and BD SMART ${ }^{T M}$ A oligonucleotide primer (5'- AAG CAG TGG TAT CAA CGC AGA GTA CGC GGG -3'). The first-strand cDNA was diluted to a final volume of $40 \mu$ with $1 \mathrm{X}$ TE buffer $(10 \mathrm{mM}$ Tris-HCl, $1 \mathrm{mM}$ EDTA, pH 8.0) and used to generate second-strand cDNA by longdistance PCR with BD Advantage 2 polymerase mix (BD Bioscience) using PCR primer II A (5'- AAG CAG TGG TAT CAA CGC AGA GT -3') and following the manufacturer's instructions. The PCR-amplified second-strand cDNA was purified using column chromatography and then digested with $10 \mathrm{U} / \mu \mathrm{IRsal}$ in a final volume of $50 \mu \mathrm{l}$ at $37^{\circ} \mathrm{C}$ for 3 hto obtain blunt-ended fragments. The final concentration of digested second-strand cDNA was $300 \mu \mathrm{g} / \mu \mathrm{l}$.

\section{Suppression subtractive hybridization}

Purified two-target CDNA was used for SSH using a Clontech PCR selected CDNA subtraction kit (BD Bioscience) according to the manufacturer's instructions. Tester CDNA (human ES cell or human NPC) was ligated to adaptor 1 and adaptor 2R in separate ligation reactions at $16^{\circ} \mathrm{C}$ overnight using $400 \mathrm{U} / \mu \mathrm{l} \mathrm{T} 4$ ligase. Driver CDNA (human NPC or human ES cells) was not ligated to adaptors. After ligation, two samples were subjected to hybridization. In the first sample, an excess of driver mRNA was added to each adaptor-ligated tester CDNA in the hybridization buffer, heat-denatured at $98^{\circ} \mathrm{Cfor} 1.5 \mathrm{~min}$ and then allowed to anneal at $68^{\circ} \mathrm{C}$ for $8 \mathrm{~h}$. Next, two primary hybridization samples were mixed together without denaturing, and freshly denatured driver CDNA was added to the sample and allowed to anneal at $68^{\circ} \mathrm{C}$ overnight. After a second hybridization, samples were diluted in $200 \mu$ dilution buffer $(20 \mathrm{mM} \mathrm{HEPES}, 50 \mathrm{mM} \mathrm{NaCl}, 0.2$ $\mathrm{mM}$ EDTA) at $68^{\circ} \mathrm{C}$ for $7 \mathrm{~min}$. This hybrid cDNA was used in PCR to amplify the desired differentially expressed sequences using $50 \mathrm{X}$ Advantage cDNA Polymerase PCR Kit (BD Bioscience). First-round PCR amplifications were performed using PCR primer 1, and secondround PCR amplifications were performed using nested primer 1 and nested primer 2R. First-round PCR was performed using the following cycling parameters. Then, amplified second-round PCR product was cloned directly into the pGEM-T Easy vector (Promega, Madison, WI, USA) and transformed into Escherichia coli DH5a cells. Plasmid DNA from each clone was purified, and the inserts were confirmed by digestion with EcoRI(NEB, England). Successfully cloned cDNA fragments were sequenced using the T7 promoter primer and the Macrogen sequencing service (http://dna.macrogen.com/kor).

\section{Bioinformatics analysis}


The nucleotide sequences were compared against all sequences in the non-redundant nucleotide database at NCBI (National Center for Biotechnology Information) using the Basic Local Alignment Search Tool program (http://www.ncbi.nlm.hih.gov/BLAST). Subtracted genes distributed ontology using NCBI database (nucleotide database).

\section{RT-PCR (Reverse transcription PCR)}

To validate differential expression between the cell types, we also performed RT-PCR. Full-length cDNA was synthesized using the SuperScriptll First-strand Synthesis system (Invitrogen, Carlsbad, CA, USA). The list of primers used for RT-PCR is provided (S1 table).

\section{Quantitative RT-PCR}

Real time PCR was performed using a QuantiTect SYPR green PCR kin (QIAGEN, Hilden, Germany) and the Real time PCR Detected System (Bio-rad). The list of primers used for quantitative RT-PCR is provided (S2table ).

\section{Statistical analysis}

The data are presented as the mean \pm S.E.M. from at least three independent experiments. The significant differences were analyzed using Student's t-test. P-values $<0.05$ were considered statistically significant.

\section{Results}

\section{SSH analysis of subtracted clones from human ES cells compared with NP cells derived from human ES cells}

We performed SSH and identified and characterized subtracted clones of one hundred twenty genes, including known genes (77\%), redundant genes (10\%) and ribosomal RNA (12\%) (Fig. 1A). To analyze these data, we categorized these genes according to cellular process in human ES cells in silico analysis. Human ES cell subtracted genes were associated with molecular functions including apoptosis, cell adhesion, cell division, development, immune response, metabolism, proliferation, RNA processing, transcription and noncoding RNA (Fig. 2A). Most of the subtracted genes in human ES cells involved metabolism (37\%) or development (18\%). The subtracted genes of human ES cells are summarized in Table 1. 
Table 1

Summary of subtracted clones in human ES cells

\begin{tabular}{|c|c|c|c|c|c|c|c|}
\hline & Gene & Full name & Accession Num. & Function & Location & Redundant & PMID \\
\hline 1 & FASTKD1 & $\begin{array}{l}\text { Homo sapiens FAST kinase } \\
\text { domains } 1 \text { (FASTKD1), } \\
\text { transcript variant } 1, \text { mRNA }\end{array}$ & NM_024622.4 & Apoptosis & $2 q 31$ & & \\
\hline 2 & $F X R 1$ & $\begin{array}{l}\text { Homo sapiens fragile } X \\
\text { mental retardation, autosomal } \\
\text { homolog } 1 \text { (FXR1), transcript } \\
\text { variant } 1 \text {, mRNA }\end{array}$ & NM_005087.3 & Apoptosis & $3 q 28$ & & 20197067 \\
\hline 3 & $J A D E 1$ & $\begin{array}{l}\text { Homo sapiens jade family } \\
\text { PHD finger } 1 \text { (JADE1), } \\
\text { transcript variant 1, mRNA }\end{array}$ & NM_199320.3 & Apoptosis & $4 q 26-q 27$ & & \\
\hline 4 & $N A C A$ & $\begin{array}{l}\text { Homo sapiens nascent } \\
\text { polypeptide-associated } \\
\text { complex alpha subunit } \\
\text { (NACA), transcript variant 1, } \\
\text { mRNA }\end{array}$ & NM_001113203.2 & Apoptosis & $\begin{array}{l}\text { 12q23- } \\
\text { q24.1 }\end{array}$ & & 22154550 \\
\hline 5 & TERF1 & $\begin{array}{l}\text { Homo sapiens telomeric } \\
\text { repeat binding factor (NIMA- } \\
\text { interacting) } 1 \text { (TERF1), } \\
\text { transcript variant } 1, \text { mRNA }\end{array}$ & NM_017489.2 & Apoptosis & $8 q 21.11$ & & 15614775 \\
\hline 6 & TMA7 & $\begin{array}{l}\text { Homo sapiens translation } \\
\text { machinery associated } 7 \\
\text { homolog (S. cerevisiae) } \\
\text { (TMA7), mRNA }\end{array}$ & NM_015933.4 & Apoptosis & 3p21.31 & & \\
\hline 7 & TMBIM6 & $\begin{array}{l}\text { Homo sapiens } \\
\text { transmembrane BAX inhibitor } \\
\text { motif containing } 6 \text { (TMBIM6), } \\
\text { transcript variant 1, mRNA }\end{array}$ & NM_003217.2 & Apoptosis & $12 q 13.12$ & & 22906541 \\
\hline 8 & WNK3 & $\begin{array}{l}\text { Homo sapiens WNK lysine } \\
\text { deficient protein kinase } 3 \\
\text { (WNK3), transcript variant } 1 \text {, } \\
\text { mRNA }\end{array}$ & NM_020922.4 & Apoptosis & Xp11.22 & & 26069258 \\
\hline 9 & YWHAZ & $\begin{array}{l}\text { Homo sapiens tyrosine 3- } \\
\text { monooxygenase/tryptophan } \\
\text { 5-monooxygenase activation } \\
\text { protein, zeta (YWHAZ), } \\
\text { transcript variant 1, mRNA }\end{array}$ & NM_003406.3 & Apoptosis & $8 q 23.1$ & & 21802640 \\
\hline 10 & PCDH15 & $\begin{array}{l}\text { Homo sapiens protocadherin- } \\
\text { related } 15 \text { (PCDH15), } \\
\text { RefSeqGene on chromosome } \\
10\end{array}$ & NM_001142763.1 & $\begin{array}{l}\text { Cell } \\
\text { adhesion }\end{array}$ & $10 q 21.1$ & & 16904662 \\
\hline 11 & PCDH18 & $\begin{array}{l}\text { Homo sapiens protocadherin } \\
18 \text { (PCDH18), transcript } \\
\text { variant } 1 \text {, mRNA }\end{array}$ & NM_019035.4 & $\begin{array}{l}\text { Cell } \\
\text { adhesion }\end{array}$ & $4 q 31$ & 2 & $\begin{array}{l}18468594 \\
225671294\end{array}$ \\
\hline 12 & PTPRF & $\begin{array}{l}\text { Homo sapiens protein tyrosine } \\
\text { phosphatase, receptor type, } F \\
\text { (PTPRF), transcript variant } 1 \text {, } \\
\text { mRNA }\end{array}$ & NM_002840.3 & $\begin{array}{l}\text { Cell } \\
\text { adhesion }\end{array}$ & $1 p 34$ & & 16784531 \\
\hline 13 & STOM & $\begin{array}{l}\text { Homo sapiens stomatin } \\
\text { (STOM), transcript variant } 1 \text {, } \\
\text { mRNA }\end{array}$ & NM_004099.5 & $\begin{array}{l}\text { Cell } \\
\text { adhesion }\end{array}$ & $9 q 34.1$ & & 19379682 \\
\hline 14 & ASUN & $\begin{array}{l}\text { Homo sapiens asunder } \\
\text { spermatogenesis regulator } \\
\text { (ASUN), mRNA }\end{array}$ & NM_018164.2 & Cell division & $12 p 11.23$ & & \\
\hline 15 & AURKA & $\begin{array}{l}\text { Homo sapiens aurora kinase A } \\
\text { (AURKA), transcript variant } 1 \text {, } \\
\text { mRNA }\end{array}$ & NM_198433.1 & Cell division & $20 q 13$ & & $\begin{array}{l}23011139 \\
24019927\end{array}$ \\
\hline
\end{tabular}




\begin{tabular}{|c|c|c|c|c|c|c|c|}
\hline & Gene & Full name & Accession Num. & Function & Location & Redundant & PMID \\
\hline 16 & HAUS1 & $\begin{array}{l}\text { Homo sapiens HAUS augmin- } \\
\text { like complex, subunit } 1 \\
\text { (HAUS1), transcript variant } 1 \text {, } \\
\text { mRNA }\end{array}$ & NM_138443.3 & Cell division & $18 q 21.1$ & & \\
\hline 17 & HSP90AA1 & $\begin{array}{l}\text { Homo sapiens heat shock } \\
\text { protein 90kDa alpha } \\
\text { (cytosolic), class A member } 1 \\
\text { (HSP90AA1), transcript variant } \\
1 \text {, mRNA }\end{array}$ & NM_001017963.2 & Cell division & $14 q 32.33$ & 2 & 26071189 \\
\hline 18 & ORC3 & $\begin{array}{l}\text { Homo sapiens origin } \\
\text { recognition complex, subunit } 3 \\
\text { (ORC3), transcript variant } 1 \text {, } \\
\text { mRNA }\end{array}$ & NM_181837.2 & Cell division & $\begin{array}{l}\text { 6q14.3- } \\
\text { q16.1 }\end{array}$ & & $\begin{array}{l}10402192, \\
23110156, \\
23349620\end{array}$ \\
\hline 19 & SKIL & $\begin{array}{l}\text { Homo sapiens SKI-like proto- } \\
\text { oncogene (SKIL), transcript } \\
\text { variant } 1 \text {, mRNA }\end{array}$ & NM_005414.4 & Cell division & $3 q 26$ & 2 & 17202138 \\
\hline 20 & SMC3 & $\begin{array}{l}\text { Homo sapiens structural } \\
\text { maintenance of chromosomes } \\
3 \text { (SMC3), mRNA }\end{array}$ & NM_005445.3 & Cell division & $10 q 25$ & & 26438359 \\
\hline 21 & YTHDF3 & $\begin{array}{l}\text { Homo sapiens YTH domain } \\
\text { family, member } 3 \text { (YTHDF3), } \\
\text { transcript variant 1, mRNA }\end{array}$ & NM_152758.5 & Cell division & $8 q 12.3$ & & \\
\hline 28 & ACVR2A & $\begin{array}{l}\text { Homo sapiens activin A } \\
\text { receptor, type IIA (ACVR2A), } \\
\text { transcript variant } 1 \text {, mRNA }\end{array}$ & NM_001278579.1 & Development & $2 \mathrm{q} 22.3$ & & $\begin{array}{l}18436533 \\
19342382\end{array}$ \\
\hline 24 & ARL6IP1 & $\begin{array}{l}\text { Homo sapiens ADP- } \\
\text { ribosylation factor-like } 6 \\
\text { interacting protein } 1 \\
\text { (ARL6IP1), mRNA }\end{array}$ & NM_015161.1 & Development & $\begin{array}{l}\text { 16p12- } \\
\text { p11.2 }\end{array}$ & & \\
\hline 25 & CD9 & $\begin{array}{l}\text { Homo sapiens CD9 molecule } \\
\text { (CD9), mRNA }\end{array}$ & NM_001769.3 & Development & $12 \mathrm{p} 13.3$ & 2 & $\begin{array}{l}15742316 . \\
11950938\end{array}$ \\
\hline 26 & $\mathrm{CDH} 1$ & $\begin{array}{l}\text { Homo sapiens cadherin 1, type } \\
1, \text { E-cadherin (epithelial) } \\
\text { (CDH1), mRNA }\end{array}$ & NM_004360.3 & Development & $16 q 22.1$ & & $\begin{array}{l}20473026 \\
24266635\end{array}$ \\
\hline 27 & DPYSL2 & $\begin{array}{l}\text { Homo sapiens } \\
\text { dihydropyrimidinase-like } 2 \\
\text { (DPYSL2), transcript variant } 1 \text {, } \\
\text { mRNA }\end{array}$ & NM_001197293.2 & Development & $8 p 22-p 21$ & & 19926752 \\
\hline 28 & FANCD2 & $\begin{array}{l}\text { Homo sapiens Fanconi } \\
\text { anemia, complementation } \\
\text { group D2 (FANCD2), transcript } \\
\text { variant } 1, \text { mRNA }\end{array}$ & NM_033084.3 & Development & $3 p 26$ & & $\begin{array}{l}22683204 \\
21458466\end{array}$ \\
\hline 29 & IARS & $\begin{array}{l}\text { Homo sapiens isoleucyl-tRNA } \\
\text { synthetase (IARS), transcript } \\
\text { variant } 1, \mathrm{mRNA}\end{array}$ & NM_002161.5 & Development & $9 q 21$ & & \\
\hline 30 & $N D C 1$ & $\begin{array}{l}\text { Homo sapiens NDC1 } \\
\text { transmembrane nucleoporin } \\
\text { (NDC1), transcript variant } 1 \text {, } \\
\text { mRNA }\end{array}$ & NM_018087.4 & Development & $1 \mathrm{p} 32.3$ & 2 & \\
\hline 31 & PGK1 & $\begin{array}{l}\text { Homo sapiens } \\
\text { phosphoglycerate kinase } 1 \\
\text { (PGK1), mRNA }\end{array}$ & NM_000291.3 & Development & Xq13.3 & & 18447643 \\
\hline 32 & RB1CC1 & $\begin{array}{l}\text { Homo sapiens RB1-inducible } \\
\text { coiled-coil } 1 \text { (RB1CC1), } \\
\text { transcript variant 1, mRNA }\end{array}$ & NM_014781.4 & Development & $8 q 11$ & & $\begin{array}{l}22184008 \\
15968549\end{array}$ \\
\hline
\end{tabular}




\begin{tabular}{|c|c|c|c|c|c|c|c|}
\hline & Gene & Full name & Accession Num. & Function & Location & Redundant & PMID \\
\hline 33 & SORL 1 & $\begin{array}{l}\text { Homo sapiens sortilin-related } \\
\text { receptor, L(DLR class) A } \\
\text { repeats containing (SORL1), } \\
\text { mRNA }\end{array}$ & NM_003105.5 & Development & $\begin{array}{l}11 \mathrm{q} 23.2- \\
\text { q24.2 }\end{array}$ & & 25772071 \\
\hline 34 & SPEN & $\begin{array}{l}\text { Homo sapiens spen family } \\
\text { transcriptional repressor } \\
\text { (SPEN), mRNA }\end{array}$ & NM_015001.2 & Development & $1 p 36$ & & 26190100 \\
\hline 35 & TFRC & $\begin{array}{l}\text { Homo sapiens transferrin } \\
\text { receptor (TFRC), transcript } \\
\text { variant } 1 \text {, mRNA }\end{array}$ & NM_003234.2 & Development & $3 q 29$ & 2 & 22595340 \\
\hline 36 & UGCG & $\begin{array}{l}\text { Homo sapiens UDP-glucose } \\
\text { ceramide glucosyltransferase } \\
\text { (UGCG), mRNA }\end{array}$ & NM_003358.2 & Development & $9 q 31$ & & $\begin{array}{l}19745600 \\
10430909\end{array}$ \\
\hline 37 & USP9X & $\begin{array}{l}\text { Homo sapiens ubiquitin } \\
\text { specific peptidase } 9 \text {, X-linked } \\
\text { (USP9X), transcript variant } 3 \text {, } \\
\text { mRNA }\end{array}$ & NM_001039590.2 & Development & Xp11.4 & 4 & 19176755 \\
\hline 38 & ZNF281 & $\begin{array}{l}\text { Homo sapiens zinc finger } \\
\text { protein } 281 \text { (ZNF281), } \\
\text { transcript variant 1, mRNA }\end{array}$ & NM_012482.4 & Development & $1 \mathrm{q} 32.1$ & & 22963690 \\
\hline 39 & IFITM1 & $\begin{array}{l}\text { Homo sapiens interferon } \\
\text { induced transmembrane } \\
\text { protein } 1 \text { (IFITM1), mRNA }\end{array}$ & NM_003641.3 & $\begin{array}{l}\text { Immune } \\
\text { response }\end{array}$ & $11 \mathrm{p} 15.5$ & & $\begin{array}{l}22634173, \\
25896322\end{array}$ \\
\hline 40 & HSPD1 & $\begin{array}{l}\text { Homo sapiens heat shock } \\
60 \mathrm{kDa} \text { protein } 1 \text { (chaperonin) } \\
\text { (HSPD 1), transcript variant 2, } \\
\text { mRNA }\end{array}$ & NM_199440.1 & $\begin{array}{l}\text { Immune } \\
\text { response }\end{array}$ & $2 q 33.1$ & & $\begin{array}{l}18047272 \\
20954177\end{array}$ \\
\hline 41 & SLC39A10 & $\begin{array}{l}\text { Homo sapiens solute carrier } \\
\text { family } 39 \text { (zinc transporter), } \\
\text { member } 10 \text { (SLC39A10), } \\
\text { transcript variant 1, mRNA }\end{array}$ & NM_001127257.1 & $\begin{array}{l}\text { Immune } \\
\text { response }\end{array}$ & $2 q 32.3$ & & \\
\hline 42 & AASS & $\begin{array}{l}\text { Homo sapiens aminoadipate- } \\
\text { semialdehyde synthase } \\
\text { (AASS), mRNA }\end{array}$ & NM_005763.3 & Metabolism & $7 q 31.3$ & & \\
\hline 43 & $A C P 1$ & $\begin{array}{l}\text { Homo sapiens acid } \\
\text { phosphatase } 1 \text {, soluble } \\
\text { (ACP1), transcript variant 2, } \\
\text { mRNA }\end{array}$ & NM_007099.3 & Metabolism & $2 p 25$ & & 25159695 \\
\hline 44 & ATP5C1 & $\begin{array}{l}\text { Homo sapiens ATP synthase, } \\
\text { H + transporting, mitochondrial } \\
\text { F1 complex, gamma } \\
\text { polypeptide } 1 \text { (ATP5C1), } \\
\text { transcript variant } 1, \text { mRNA }\end{array}$ & NM_001001973.1 & Metabolism & 10p15.1 & & \\
\hline 45 & AZIN1 & $\begin{array}{l}\text { Homo sapiens antizyme } \\
\text { inhibitor } 1 \text { (AZIN1), transcript } \\
\text { variant } 1 \text {, mRNA }\end{array}$ & NM_015878.5 & Metabolism & $8 q 22.3$ & & \\
\hline 46 & CCT2 & $\begin{array}{l}\text { Homo sapiens chaperonin } \\
\text { containing TCP1, subunit } 2 \\
\text { (beta) (CCT2), transcript } \\
\text { variant } 1, \text { mRNA }\end{array}$ & NM_006431.2 & Metabolism & $12 q 15$ & & $\begin{array}{l}21640791, \\
21404461\end{array}$ \\
\hline 46 & CECR2 & $\begin{array}{l}\text { Homo sapiens cat eye } \\
\text { syndrome chromosome } \\
\text { region, candidate } 2 \text { (CECR2), } \\
\text { transcript variant } 1 \text {, mRNA }\end{array}$ & NM_001290047.1 & Metabolism & $22 q 11.2$ & & \\
\hline 47 & COPZ1 & $\begin{array}{l}\text { Homo sapiens coatomer } \\
\text { protein complex, subunit zeta } \\
1 \text { (COPZ1), transcript variant } 1 \text {, } \\
\text { mRNA }\end{array}$ & NM_016057.2 & Metabolism & $\begin{array}{l}12 q 13.2- \\
\text { q13.3 }\end{array}$ & & \\
\hline
\end{tabular}




\begin{tabular}{|c|c|c|c|c|c|c|c|}
\hline & Gene & Full name & Accession Num. & Function & Location & Redundant & PMID \\
\hline 48 & $D E K$ & $\begin{array}{l}\text { Homo sapiens DEK proto- } \\
\text { oncogene (DEK), transcript } \\
\text { variant } 1 \text {, mRNA }\end{array}$ & NM_003472.3 & Metabolism & $6 p 22.3$ & & $\begin{array}{l}21943234 \\
10391928\end{array}$ \\
\hline 49 & EEF1A1 & $\begin{array}{l}\text { Homo sapiens eukaryotic } \\
\text { translation elongation factor } 1 \\
\text { alpha } 1 \text { (EEF1A1), mRNA }\end{array}$ & NM_001402.5 & Metabolism & $6 q 14.1$ & & $\begin{array}{l}\text { 15540898, } \\
19157425\end{array}$ \\
\hline 50 & EIF4A2 & $\begin{array}{l}\text { Homo sapiens eukaryotic } \\
\text { translation initiation factor } \\
\text { 4A2 (EIF4A2), mRNA }\end{array}$ & NM_001967.3 & Metabolism & $3 q 28$ & & \\
\hline 51 & GARS & $\begin{array}{l}\text { Homo sapiens glycyl-tRNA } \\
\text { synthetase (GARS), mRNA }\end{array}$ & NM_002047.2 & Metabolism & $7 p 15$ & & 22791832 \\
\hline 52 & G3BP1 & $\begin{array}{l}\text { Homo sapiens GTPase } \\
\text { activating protein (SH3 } \\
\text { domain) binding protein } 1 \\
\text { (G3BP1), transcript variant } \mathrm{X} 1 \text {, } \\
\text { mRNA }\end{array}$ & NM_005754.2 & Metabolism & $5 q 33.1$ & & \\
\hline 53 & GPN1 & $\begin{array}{l}\text { Homo sapiens GPN-loop } \\
\text { GTPase } 1 \text { (GPN1), transcript } \\
\text { variant } 1 \text {, mRNA }\end{array}$ & NM_007266.3 & Metabolism & $2 p 23.3$ & & \\
\hline 54 & JMJD1C & $\begin{array}{l}\text { Homo sapiens jumonji domain } \\
\text { containing } 1 C \text { (JMJD1C), } \\
\text { transcript variant 1, mRNA }\end{array}$ & NM_032776.2 & Metabolism & $10 q 21.3$ & & 24318875 \\
\hline 55 & $\angle R B A$ & $\begin{array}{l}\text { Homo sapiens LPS-responsive } \\
\text { vesicle trafficking, beach and } \\
\text { anchor containing (LRBA), } \\
\text { transcript variant } 1 \text {, mRNA }\end{array}$ & NM_001199282 & Metabolism & $4 q 31.3$ & & \\
\hline 56 & LYPLA1 & $\begin{array}{l}\text { Homo sapiens } \\
\text { lysophospholipase I (LYPLA1), } \\
\text { transcript variant 1, mRNA }\end{array}$ & NM_006330.3 & Metabolism & $8 q 11.23$ & & \\
\hline 57 & $M Y L 6$ & $\begin{array}{l}\text { Homo sapiens myosin, light } \\
\text { chain 6, alkali, smooth muscle } \\
\text { and non-muscle (MYL6), } \\
\text { transcript variant } 2 \text {, mRNA }\end{array}$ & NM_079423.3 & Metabolism & $12 q 13.2$ & 2 & \\
\hline 58 & NDUFS5 & $\begin{array}{l}\text { Homo sapiens NADH } \\
\text { dehydrogenase (ubiquinone) } \\
\text { Fe-S protein } 5,15 \mathrm{kDa} \text { (NADH- } \\
\text { coenzyme } \mathrm{Q} \text { reductase) } \\
\text { (NDUFS5), transcript variant } 1 \text {, } \\
\text { mRNA }\end{array}$ & NM_004552.2 & Metabolism & $\begin{array}{l}1 \text { p34.2- } \\
\text { p33 }\end{array}$ & & \\
\hline 59 & $N E C A B 1$ & $\begin{array}{l}\text { Homo sapiens N-terminal EF- } \\
\text { hand calcium binding protein } \\
1 \text { (NECAB1), mRNA }\end{array}$ & NM_022351.4 & Metabolism & $8 q 21.3$ & & 24616509 \\
\hline 60 & OTUD4 & $\begin{array}{l}\text { Homo sapiens OTU } \\
\text { deubiquitinase } 4 \text { (OTUD4), } \\
\text { transcript variant 3, mRNA }\end{array}$ & NM_001102653.1 & Metabolism & 10p12.2 & & \\
\hline 61 & PDK1 & $\begin{array}{l}\text { Homo sapiens pyruvate } \\
\text { dehydrogenase kinase, } \\
\text { isozyme } 1 \text { (PDK1), transcript } \\
\text { variant } 1 \text {, mRNA }\end{array}$ & NM_001278549.1 & Metabolism & $2 q 31.1$ & & $\begin{array}{l}21540297 \\
18514190\end{array}$ \\
\hline 62 & PLOD2 & $\begin{array}{l}\text { Homo sapiens procollagen- } \\
\text { lysine, 2-oxoglutarate 5- } \\
\text { dioxygenase } 2 \text { (PLOD2), } \\
\text { transcript variant 1, mRNA }\end{array}$ & NM_182943.2 & Metabolism & $3 q 24$ & & 17553463 \\
\hline 63 & PSMD2 & $\begin{array}{l}\text { Homo sapiens proteasome } \\
\text { (prosome, macropain) 26S } \\
\text { subunit, non-ATPase, } 2 \\
\text { (PSMD2), transcript variant 1, } \\
\text { mRNA }\end{array}$ & NM_002808.4 & Metabolism & $3 q 27.1$ & & \\
\hline
\end{tabular}




\begin{tabular}{|c|c|c|c|c|c|c|c|}
\hline & Gene & Full name & Accession Num. & Function & Location & Redundant & PMID \\
\hline 64 & RASSF3 & $\begin{array}{l}\text { Homo sapiens Ras } \\
\text { association (RalGDS/AF-6) } \\
\text { domain family member } 3 \\
\text { (RASSF3), transcript variant 1, } \\
\text { mRNA }\end{array}$ & NM_178169.3 & Metabolism & $12 q 14.2$ & & \\
\hline 65 & RPL 14 & $\begin{array}{l}\text { Homo sapiens ribosomal } \\
\text { protein L14 (RPL14), transcript } \\
\text { variant } 2 \text {, mRNA }\end{array}$ & NM_003973.4 & Metabolism & $\begin{array}{l}\text { 3p22- } \\
\text { p21.2 }\end{array}$ & & \\
\hline 66 & SEPHS1 & $\begin{array}{l}\text { Homo sapiens } \\
\text { selenophosphate synthetase } 1 \\
\text { (SEPHS1), transcript variant } 1 \text {, } \\
\text { mRNA }\end{array}$ & NM_012247.4 & Metabolism & 10p14 & & 19128516 \\
\hline 67 & SERINC5 & $\begin{array}{l}\text { Homo sapiens serine } \\
\text { incorporator } 5 \text { (SERINC5), } \\
\text { transcript variant 1, mRNA }\end{array}$ & NM_001174072.2 & Metabolism & $5 q 14.1$ & & \\
\hline 68 & $S L C 2 A 3$ & $\begin{array}{l}\text { Homo sapiens solute carrier } \\
\text { family } 2 \text { (facilitated glucose } \\
\text { transporter), member } 3 \\
\text { (SLC2A3), mRNA }\end{array}$ & NM_006931.2 & Metabolism & $12 \mathrm{p} 13.3$ & 2 & $\begin{array}{l}18948350 \\
16221986\end{array}$ \\
\hline 69 & SLC44A1 & $\begin{array}{l}\text { Homo sapiens solute carrier } \\
\text { family } 44 \text { (choline transporter), } \\
\text { member } 1 \text { (SLC44A1), } \\
\text { transcript variant 1, mRNA }\end{array}$ & NM_080546.4 & Metabolism & $9 q 31.2$ & & \\
\hline 70 & SSR2 & $\begin{array}{l}\text { Homo sapiens signal } \\
\text { sequence receptor, beta } \\
\text { (translocon-associated protein } \\
\text { beta) (SSR2), mRNA }\end{array}$ & NM_003145.3 & Metabolism & $1 q 21-q 23$ & 2 & \\
\hline 71 & UBE2H & $\begin{array}{l}\text { Homo sapiens ubiquitin- } \\
\text { conjugating enzyme E2H } \\
\text { (UBE2H), transcript variant } 1 \text {, } \\
\text { mRNA }\end{array}$ & NM_003344.3 & Metabolism & $7 q 32$ & & \\
\hline 72 & UBE2W & $\begin{array}{l}\text { Homo sapiens ubiquitin- } \\
\text { conjugating enzyme E2W } \\
\text { (putative) (UBE2W), transcript } \\
\text { variant 1, mRNA }\end{array}$ & NM_001001481.2 & Metabolism & $8 q 21.11$ & & \\
\hline 73 & UGP2 & $\begin{array}{l}\text { Homo sapiens UDP-glucose } \\
\text { pyrophosphorylase } 2 \text { (UGP2), } \\
\text { transcript variant 1, mRNA }\end{array}$ & NM_006759.3 & Metabolism & 2p14-p13 & & \\
\hline 74 & $C D 24$ & $\begin{array}{l}\text { Homo sapiens CD24 molecule } \\
\text { (CD24), transcript variant } 1 \text {, } \\
\text { mRNA }\end{array}$ & NM_013230.3 & Proliferation & $6 q 21$ & & $\begin{array}{l}\text { 15614775, } \\
17204602, \\
19579288\end{array}$ \\
\hline 75 & GPC4 & $\begin{array}{l}\text { Homo sapiens glypican } 4 \\
\text { (GPC4), mRNA }\end{array}$ & NM_001448.2 & Proliferation & Xq26.1 & & 22761013 \\
\hline 76 & $N A P 1 L 1$ & $\begin{array}{l}\text { Homo sapiens nucleosome } \\
\text { assembly protein 1-like } 1 \\
\text { (NAP1L1), transcript variant 1, } \\
\text { mRNA }\end{array}$ & NM_139207.2 & Proliferation & $12 q 21.2$ & & 23260146 \\
\hline 77 & NPM1 & $\begin{array}{l}\text { Homo sapiens nucleophosmin } \\
\text { (nucleolar phosphoprotein } \\
\text { B23, numatrin) (NPM1), } \\
\text { transcript variant 1, mRNA }\end{array}$ & NM_002520.6 & Proliferation & $5 q 35.1$ & & 24798243 \\
\hline 78 & SLC35F2 & $\begin{array}{l}\text { Homo sapiens solute carrier } \\
\text { family 35, member F2 } \\
\text { (SLC35F2), mRNA }\end{array}$ & NM_017515.4 & Proliferation & $11 q 22.3$ & & \\
\hline 79 & CPSF6 & $\begin{array}{l}\text { Homo sapiens cleavage and } \\
\text { polyadenylation specific factor } \\
6,68 \mathrm{kDa} \text { (CPSF6), transcript } \\
\text { variant } 1 \text {, mRNA }\end{array}$ & NM_007007.2 & $\begin{array}{l}\text { RNA } \\
\text { processing }\end{array}$ & $12 q 15$ & & \\
\hline
\end{tabular}




\begin{tabular}{|c|c|c|c|c|c|c|c|}
\hline & Gene & Full name & Accession Num. & Function & Location & Redundant & PMID \\
\hline 80 & HNRNPA2B1 & $\begin{array}{l}\text { Homo sapiens heterogeneous } \\
\text { nuclear ribonucleoprotein } \\
\text { A2/B1 (HNRNPA2B1), } \\
\text { transcript variant A2, mRNA }\end{array}$ & NM_002137.3 & $\begin{array}{l}\text { RNA } \\
\text { processing }\end{array}$ & 7p15 & & 23495120 \\
\hline 81 & HNRNPA3 & $\begin{array}{l}\text { Homo sapiens heterogeneous } \\
\text { nuclear ribonucleoprotein A3 } \\
\text { (HNRNPA3), mRNA }\end{array}$ & NM_194247.2 & $\begin{array}{l}\text { RNA } \\
\text { processing }\end{array}$ & $2 q 31.2$ & & \\
\hline 82 & HSPA8 & $\begin{array}{l}\text { Homo sapiens heat shock } \\
70 \mathrm{kDa} \text { protein } 8 \text { (HSPA8), } \\
\text { transcript variant } 1 \text {, mRNA }\end{array}$ & NM_006597.5 & $\begin{array}{l}\text { RNA } \\
\text { processing }\end{array}$ & $11 q 24.1$ & & 16100000 \\
\hline 83 & $L A R P 7$ & $\begin{array}{l}\text { Homo sapiens La } \\
\text { ribonucleoprotein domain } \\
\text { family, member } 7 \text { (LARP7), } \\
\text { transcript variant 2, mRNA }\end{array}$ & NM_006597.5 & $\begin{array}{l}\text { RNA } \\
\text { processing }\end{array}$ & $4 q 25$ & & 24768001 \\
\hline 84 & MATR3 & $\begin{array}{l}\text { Homo sapiens matrin } 3 \\
\text { (MATR3), transcript variant } 1 \text {, } \\
\text { mRNA }\end{array}$ & NM_199189.2 & $\begin{array}{l}\text { RNA } \\
\text { processing }\end{array}$ & $5 q 31.2$ & & \\
\hline 85 & DPPA4 & $\begin{array}{l}\text { Homo sapiens developmental } \\
\text { pluripotency associated } 4 \\
\text { (DPPA4), mRNA }\end{array}$ & NM_018189.3 & Transcription & $3 q 13.13$ & 2 & 25421462 \\
\hline 86 & DРY30 & $\begin{array}{l}\text { Homo sapiens dpy-30 } \\
\text { homolog (C. elegans) } \\
\text { (DPY30), mRNA }\end{array}$ & NM_032574.2 & Transcription & $2 p 22.3$ & & \\
\hline 87 & EGR1 & $\begin{array}{l}\text { Homo sapiens early growth } \\
\text { response } 1 \text { (EGR1), mRNA }\end{array}$ & NM_001964.2 & Transcription & $5 q 31.1$ & & 19798744 \\
\hline 88 & $H 2 A F Z$ & $\begin{array}{l}\text { Homo sapiens H2A histone } \\
\text { family, member Z (H2AFZ), } \\
\text { mRNA }\end{array}$ & NM_002106.3 & Transcription & $4 q 24$ & & 21752451 \\
\hline 89 & $E S R G$ & $\begin{array}{l}\text { Homo sapiens embryonic } \\
\text { stem cell related (non-protein } \\
\text { coding) (ESRG), long non- } \\
\text { coding RNA }\end{array}$ & NR_027122.1 & $\begin{array}{l}\text { Non-cording } \\
\text { RNA }\end{array}$ & $3 p 14.3$ & & \\
\hline 90 & MALAT1 & $\begin{array}{l}\text { Homo sapiens metastasis } \\
\text { associated lung } \\
\text { adenocarcinoma transcript } 1 \\
\text { (non-protein coding) } \\
\text { (MALAT1), long non-coding } \\
\text { RNA }\end{array}$ & NR_002819.2 & $\begin{array}{l}\text { Non-cording } \\
\text { RNA }\end{array}$ & $11 q 13.1$ & & $\begin{array}{l}23485710 \\
25868726\end{array}$ \\
\hline
\end{tabular}

\section{SSH analysis of subtracted clones from NP cells derived from human ES cells compared with human ES cells}

In addition, we performed the inverse SSH, which yielded eighty-five subtracted clones, including known genes (73\%), redundant genes (9\%) and ribosomal RNA (18\%) (Fig. 1B). Next, we used an in silico approach to categorize the genes specific to NP cells derived from human ES cells based on cellular processes. Human ES cell-derived NP cell subtracted genes were associated with molecular functions including cell adhesion, cell division, development, metabolism, proliferation, RNA processing, transcription and non-coding RNA (Fig. 2B). Most of the subtracted genes in NP cells derived from human ES cells were associated with metabolism (31\%) and development (26\%), similar to the subtracted genes in human ES cells. The NP cell subtracted genes are summarized in Table 2. 
Table 2

Summary of subtracted clones from NP cells derived from human ES cells

\begin{tabular}{|c|c|c|c|c|c|c|c|}
\hline & Gene & Full name & Accession Num. & Function & Location & Redundant & PMID \\
\hline 1 & $C A P Z A 1$ & $\begin{array}{l}\text { Homo sapiens capping protein } \\
\text { (actin filament) muscle Z-line, } \\
\text { alpha } 1 \text { (CAPZA1), mRNA }\end{array}$ & NM_006135.2 & $\begin{array}{l}\text { Cell } \\
\text { adhesion }\end{array}$ & $1 \mathrm{p} 13.2$ & & \\
\hline 2 & CASK & $\begin{array}{l}\text { Homo sapiens } \\
\text { calcium/calmodulin-dependent } \\
\text { serine protein kinase (MAGUK } \\
\text { family) (CASK), transcript } \\
\text { variant 1, mRNA }\end{array}$ & NM_003688.3 & $\begin{array}{l}\text { Cell } \\
\text { adhesion }\end{array}$ & Xp11.4 & & 16842202 \\
\hline 3 & CCDC80 & $\begin{array}{l}\text { Homo sapiens coiled-coil } \\
\text { domain containing } 80 \\
\text { (CCDC80), transcript variant } 1 \text {, } \\
\text { mRNA }\end{array}$ & NM_199511.2 & $\begin{array}{l}\text { Cell } \\
\text { adhesion }\end{array}$ & $3 q 13.2$ & & 22384085 \\
\hline 4 & CCDC90B & $\begin{array}{l}\text { Homo sapiens coiled-coil } \\
\text { domain containing 90B } \\
\text { (CCDC90B), transcript variant } 1 \text {, } \\
\text { mRNA }\end{array}$ & NM_021825.4 & $\begin{array}{l}\text { Cell } \\
\text { adhesion }\end{array}$ & $11 q 14.1$ & & \\
\hline 5 & SPTBN1 & $\begin{array}{l}\text { Homo sapiens spectrin, beta, } \\
\text { non-erythrocytic } 1 \text { (SPTBN1), } \\
\text { transcript variant 1, mRNA }\end{array}$ & NM_003128.2 & $\begin{array}{l}\text { Cell } \\
\text { adhesion }\end{array}$ & $2 p 21$ & & \\
\hline 6 & TMOD3 & $\begin{array}{l}\text { Homo sapiens tropomodulin } 3 \\
\text { (ubiquitous) (TMOD3), mRNA }\end{array}$ & NM_014547.4 & $\begin{array}{l}\text { Cell } \\
\text { adhesion }\end{array}$ & $\begin{array}{l}15 q 21.1- \\
q 21.2\end{array}$ & & \\
\hline 7 & TRIQK & $\begin{array}{l}\text { Homo sapiens triple QxxK/R } \\
\text { motif containing (TRIQK), } \\
\text { transcript variant 1, mRNA }\end{array}$ & NM_001171796.1 & $\begin{array}{l}\text { Cell } \\
\text { adhesion }\end{array}$ & $8 q 22.1$ & 2 & \\
\hline 8 & TUBA1A & $\begin{array}{l}\text { Homo sapiens tubulin, alpha } \\
\text { 1a (TUBA1A), transcript variant } \\
\text { 1, mRNA }\end{array}$ & NM_006009.3 & $\begin{array}{l}\text { Cell } \\
\text { adhesion }\end{array}$ & $12 q 13.12$ & 2 & 23231350 \\
\hline 9 & CCNB2 & $\begin{array}{l}\text { Homo sapiens cyclin B2 } \\
\text { (CCNB2), mRNA }\end{array}$ & NM_004701.3 & Cell division & $15 q 22.2$ & & 15318809 \\
\hline 10 & CUL 1 & $\begin{array}{l}\text { Homo sapiens cullin } 1 \text { (CUL1), } \\
\text { mRNA }\end{array}$ & NM_003592.2 & Cell division & $7 q 36.1$ & 2 & 16396913 \\
\hline 11 & IST1 & $\begin{array}{l}\text { Homo sapiens increased } \\
\text { sodium tolerance } 1 \text { homolog } \\
\text { (yeast) (IST1), transcript } \\
\text { variant 1, mRNA }\end{array}$ & NM_001270975.1 & Cell division & $16 q 22.2$ & & \\
\hline 12 & PSMA5 & $\begin{array}{l}\text { Homo sapiens proteasome } \\
\text { (prosome, macropain) subunit, } \\
\text { alpha type, } 5 \text { (PSMA5), } \\
\text { transcript variant } 1, \text { mRNA }\end{array}$ & NM_002790.3 & Cell division & $1 \mathrm{p} 13$ & & \\
\hline 13 & PSMD1 & $\begin{array}{l}\text { Homo sapiens proteasome } \\
\text { (prosome, macropain) 26S } \\
\text { subunit, non-ATPase, } 1 \\
\text { (PSMD1), transcript variant 1, } \\
\text { mRNA }\end{array}$ & NM_002807.3 & Cell division & $2 q 37.1$ & 2 & 19282972 \\
\hline 14 & PSMD14 & $\begin{array}{l}\text { Homo sapiens proteasome } \\
\text { (prosome, macropain) 26S } \\
\text { subunit, non-ATPase, } 14 \\
\text { (PSMD14), mRNA }\end{array}$ & NM_005805.5 & Cell division & $2 q 24.2$ & & \\
\hline 15 & ADAM10 & $\begin{array}{l}\text { Homo sapiens ADAM } \\
\text { metallopeptidase domain } 10 \\
\text { (ADAM10), mRNA }\end{array}$ & NM_001110.3 & Development & $15 q 22$ & & 24404179 \\
\hline 16 & $C D 46$ & $\begin{array}{l}\text { Homo sapiens CD } 46 \text { molecule, } \\
\text { complement regulatory protein } \\
\text { (CD46), transcript variant a, } \\
\text { mRNA }\end{array}$ & NM_002389.4 & Development & $1 q 32$ & & 9386776 \\
\hline
\end{tabular}




\begin{tabular}{|c|c|c|c|c|c|c|c|}
\hline & Gene & Full name & Accession Num. & Function & Location & Redundant & PMID \\
\hline 17 & $D A D 1$ & $\begin{array}{l}\text { Homo sapiens defender } \\
\text { against cell death } 1 \text { (DAD1), } \\
\text { mRNA }\end{array}$ & NM_001344.3 & Development & $14 q 11.2$ & & 21305469 \\
\hline 18 & $D A Z A P 2$ & $\begin{array}{l}\text { Homo sapiens DAZ associated } \\
\text { protein } 2 \text { (DAZAP2), transcript } \\
\text { variant } 1 \text {, mRNA }\end{array}$ & NM_014764.3 & Development & $12 q 12$ & & 19555680 \\
\hline 19 & EIF4E & $\begin{array}{l}\text { Homo sapiens eukaryotic } \\
\text { translation initiation factor } 4 \mathrm{E} \\
\text { (EIF4E), transcript variant } 1 \text {, } \\
\text { mRNA }\end{array}$ & NM_001968.3 & Development & $4 q 23$ & & 16705177 \\
\hline 20 & GGNBP2 & $\begin{array}{l}\text { Homo sapiens gametogenetin } \\
\text { binding protein } 2 \text { (GGNBP2), } \\
\text { mRNA }\end{array}$ & NM_024835.4 & Development & $17 q 12$ & & \\
\hline 21 & HMGCS1 & $\begin{array}{l}\text { Homo sapiens 3-hydroxy-3- } \\
\text { methylglutaryl-CoA synthase } 1 \\
\text { (soluble) (HMGCS1), transcript } \\
\text { variant 1, mRNA }\end{array}$ & NM_001098272.2 & Development & 5p14-p13 & & 9425122 \\
\hline 22 & ILDR2 & $\begin{array}{l}\text { Homo sapiens } \\
\text { immunoglobulin-like domain } \\
\text { containing receptor } 2 \text { (ILDR2), } \\
\text { mRNA }\end{array}$ & NM_199351.2 & Development & $1 \mathrm{q} 24.1$ & & \\
\hline 23 & MEIS1 & $\begin{array}{l}\text { Homo sapiens Meis homeobox } \\
1 \text { (MEIS1), mRNA }\end{array}$ & NM_002398.2 & Development & $2 \mathrm{p} 14$ & & 23756022 \\
\hline 24 & NIPBL & $\begin{array}{l}\text { Homo sapiens Nipped-B } \\
\text { homolog (Drosophila) (NIPBL), } \\
\text { transcript variant } A \text {, mRNA }\end{array}$ & NM_133433.3 & Development & $5 p 13.2$ & & \\
\hline 25 & PYGO1 & $\begin{array}{l}\text { Homo sapiens pygopus family } \\
\text { PHD finger } 1 \text { (PYGO1), mRNA }\end{array}$ & NM_015617.2 & Development & $15 q 21.3$ & & \\
\hline 26 & sox4 & $\begin{array}{l}\text { Homo sapiens SRY (sex } \\
\text { determining region Y)-box } 4 \\
\text { (SOX4), mRNA }\end{array}$ & NM_003107.2 & Development & $6 p 22.3$ & 2 & $\begin{array}{l}23894955 \\
20646169\end{array}$ \\
\hline 27 & sox11 & $\begin{array}{l}\text { Homo sapiens SRY (sex } \\
\text { determining region Y)-box } 11 \\
\text { (SOX11), mRNA }\end{array}$ & NM_003108.3 & Development & $2 p 25$ & & 23874955 \\
\hline 28 & STMN1 & $\begin{array}{l}\text { Homo sapiens stathmin } 1 \\
\text { (STMN1), transcript variant } 3 \text {, } \\
\text { mRNA }\end{array}$ & NM_005563.3 & Development & $1 \mathrm{p} 36.11$ & 3 & 19526456 \\
\hline 29 & TAF8 & $\begin{array}{l}\text { Homo sapiens TAF8 RNA } \\
\text { polymerase II, TATA box } \\
\text { binding protein (TBP)-- } \\
\text { associated factor, 43kDa } \\
\text { (TAF8), mRNA }\end{array}$ & NM_138572.2 & Development & $6 p 21.1$ & & \\
\hline 30 & TPM1 & $\begin{array}{l}\text { Homo sapiens tropomyosin } 1 \\
\text { (alpha) (TPM1), transcript } \\
\text { variant Tpm1.3, mRNA }\end{array}$ & NM_001018020.1 & Development & $15 q 22.1$ & & 23918370 \\
\hline 31 & WDR19 & $\begin{array}{l}\text { Homo sapiens WD repeat } \\
\text { domain } 19 \text { (WDR19), } \\
\text { RefSeqGene on chromosome } 4\end{array}$ & NM_025132.3 & Development & $4 p 14$ & & \\
\hline 32 & $A L D H 18 A 1$ & $\begin{array}{l}\text { Homo sapiens aldehyde } \\
\text { dehydrogenase } 18 \text { family, } \\
\text { member A1 (ALDH18A1), } \\
\text { transcript variant 1, mRNA }\end{array}$ & NM_002860.3 & Metabolism & $10 q 24.3$ & & \\
\hline 33 & CBR4 & $\begin{array}{l}\text { Homo sapiens carbonyl } \\
\text { reductase } 4 \text { (CBR4), mRNA }\end{array}$ & NM_032783.4 & Metabolism & $4 q 32.3$ & & \\
\hline
\end{tabular}




\begin{tabular}{|c|c|c|c|c|c|c|c|}
\hline & Gene & Full name & Accession Num. & Function & Location & Redundant & PMID \\
\hline 34 & CHMP2B & $\begin{array}{l}\text { Homo sapiens charged } \\
\text { multivesicular body protein 2B } \\
\text { (CHMP2B), transcript variant } 1 \text {, } \\
\text { mRNA }\end{array}$ & NM_014043.3 & Metabolism & $3 p 11.2$ & & 23284619 \\
\hline 35 & $E R C C 1$ & $\begin{array}{l}\text { Homo sapiens excision repair } \\
\text { cross-complementation group } \\
8 \text { (ERCC8), transcript variant } 1 \text {, } \\
\text { mRNA }\end{array}$ & NM_000082.3 & Metabolism & $19 q 13.32$ & & $\begin{array}{l}20362516 \\
18221731\end{array}$ \\
\hline 36 & EXOSC8 & $\begin{array}{l}\text { Homo sapiens exosome } \\
\text { component } 8 \text { (EXOSC8), mRNA }\end{array}$ & NM_181503.2 & Metabolism & $13 q 13.1$ & & \\
\hline 37 & GBE1 & $\begin{array}{l}\text { Homo sapiens glucan }(1,4- \\
\text { alpha-), branching enzyme } 1 \\
\text { (GBE1), mRNA }\end{array}$ & NM_000158.3 & Metabolism & $3 p 12.3$ & & \\
\hline 38 & HPRT1 & $\begin{array}{l}\text { Homo sapiens hypoxanthine } \\
\text { phosphoribosyltransferase } 1 \\
\text { (HPRT1), mRNA }\end{array}$ & NM_000194.2 & Metabolism & $\mathrm{Xq} 26.1$ & & 24130677 \\
\hline 39 & NDUFS2 & $\begin{array}{l}\text { Homo sapiens NADH } \\
\text { dehydrogenase (ubiquinone) } \\
\text { Fe-S protein } 2,49 \mathrm{kDa} \text { (NADH- } \\
\text { coenzyme Q reductase) } \\
\text { (NDUFS2), transcript variant } 1 \text {, } \\
\text { mRNA }\end{array}$ & NM_004550.4 & Metabolism & $1 q 23$ & & \\
\hline 40 & NIPA2 & $\begin{array}{l}\text { Homo sapiens non imprinted in } \\
\text { Prader-Willi/Angelman } \\
\text { syndrome } 2 \text { (NIPA2), transcript } \\
\text { variant 1, mRNA }\end{array}$ & NM_030922.6 & Metabolism & $15 q 11.2$ & & \\
\hline 41 & OSTC & $\begin{array}{l}\text { Homo sapiens } \\
\text { oligosaccharyltransferase } \\
\text { complex subunit (non-catalytic) } \\
\text { (OSTC), transcript variant 1, } \\
\text { mRNA }\end{array}$ & NM_021227.3 & Metabolism & $4 q 25$ & & \\
\hline 42 & PAICS & $\begin{array}{l}\text { Homo sapiens } \\
\text { phosphoribosylaminoimidazole } \\
\text { carboxylase, } \\
\text { phosphoribosylaminoimidazole } \\
\text { succinocarboxamide } \\
\text { synthetase (PAICS), transcript } \\
\text { variant 1, mRNA }\end{array}$ & NM_001079525.1 & Metabolism & $4 q 12$ & & 22155494 \\
\hline 43 & PSMB3 & $\begin{array}{l}\text { Homo sapiens proteasome } \\
\text { (prosome, macropain) subunit, } \\
\text { beta type, } 3 \text { (PSMB3), transcript } \\
\text { variant 1, mRNA }\end{array}$ & NM_002795.3 & Metabolism & $17 q 12$ & & \\
\hline 44 & RPL24 & $\begin{array}{l}\text { Homo sapiens ribosomal } \\
\text { protein L24 (RPL24), mRNA }\end{array}$ & NM_000986.3 & Metabolism & $3 q 12$ & & \\
\hline 45 & RPLPO & $\begin{array}{l}\text { Homo sapiens ribosomal } \\
\text { protein, large, P0 (RPLP0), } \\
\text { transcript variant 1, mRNA }\end{array}$ & NM_001002.3 & Metabolism & $12 q 24.2$ & 2 & \\
\hline 46 & RPLP1 & $\begin{array}{l}\text { Homo sapiens ribosomal } \\
\text { protein, large, P1 (RPLP1), } \\
\text { transcript variant 1, mRNA }\end{array}$ & NM_001003.2 & Metabolism & $15 q 22$ & & \\
\hline 47 & SH3BGRL & $\begin{array}{l}\text { Homo sapiens } \mathrm{SH} 3 \text { domain } \\
\text { binding glutamate-rich protein } \\
\text { like (SH3BGR }) \text {, mRNA }\end{array}$ & NM_003022.2 & Metabolism & Xq13.3 & & \\
\hline 48 & TBC1D15 & $\begin{array}{l}\text { Homo sapiens TBC1 domain } \\
\text { family, member } 15 \text { (TBC1D15), } \\
\text { transcript variant 1, mRNA }\end{array}$ & NM_022771.4 & Metabolism & $12 q 21.1$ & & \\
\hline
\end{tabular}




\begin{tabular}{|c|c|c|c|c|c|c|c|}
\hline & Gene & Full name & Accession Num. & Function & Location & Redundant & PMID \\
\hline 49 & TRA2B & $\begin{array}{l}\text { Homo sapiens transformer } 2 \\
\text { beta homolog (Drosophila) } \\
\text { (TRA2B), transcript variant 1, } \\
\text { mRNA }\end{array}$ & NM_004593.2 & Metabolism & $\begin{array}{l}3 q 26.2- \\
q 27\end{array}$ & & $\begin{array}{l}24586484 \\
23818142\end{array}$ \\
\hline 50 & $U G D H$ & $\begin{array}{l}\text { Homo sapiens UDP-glucose 6- } \\
\text { dehydrogenase (UGDH) } \\
\text { transcript variant 1, mRNA }\end{array}$ & NM_003359.3 & Metabolism & $4 \mathrm{p} 15.1$ & & \\
\hline 51 & CREG1 & $\begin{array}{l}\text { Homo sapiens cellular } \\
\text { repressor of E1 A-stimulated } \\
\text { genes } 1 \text { (CREG1), mRNA }\end{array}$ & NM_003851.2 & Proliferation & $1 q 24$ & & 20857207 \\
\hline 52 & PEL/1 & $\begin{array}{l}\text { Homo sapiens pellino E3 } \\
\text { ubiquitin protein ligase } 1 \\
\text { (PELI1), mRNA }\end{array}$ & NM_020651.3 & Proliferation & $2 \mathrm{p} 13.3$ & & 26131354 \\
\hline 53 & SETD5 & $\begin{array}{l}\text { Homo sapiens SET domain } \\
\text { containing } 5 \text { (SETD 5), mRNA }\end{array}$ & NM_001080517.1 & Proliferation & $3 p 25.3$ & & \\
\hline 54 & HNRNPA1 & $\begin{array}{l}\text { Homo sapiens heterogeneous } \\
\text { nuclear ribonucleoprotein A1 } \\
\text { (HNRNPA1), transcript variant } \\
1 \text {, mRNA }\end{array}$ & NM_002136.2 & $\begin{array}{l}\text { RNA } \\
\text { processing }\end{array}$ & $12 q 13.1$ & 2 & \\
\hline 55 & HNRNPA2B1 & $\begin{array}{l}\text { Homo sapiens heterogeneous } \\
\text { nuclear ribonucleoprotein } \\
\text { A2/B1 (HNRNPA2B1), } \\
\text { transcript variant A2, mRNA }\end{array}$ & NM_002137.3 & $\begin{array}{l}\text { RNA } \\
\text { processing }\end{array}$ & $7 p 15$ & & 25124043 \\
\hline 56 & TPRKB & $\begin{array}{l}\text { Homo sapiens TP53RK binding } \\
\text { protein (TPRKB), mRNA }\end{array}$ & NM_016058.2 & $\begin{array}{l}\text { RNA } \\
\text { processing }\end{array}$ & $\begin{array}{l}\text { 2p24.3- } \\
\text { p24.1 }\end{array}$ & & \\
\hline 57 & TRDMT1 & $\begin{array}{l}\text { Homo sapiens tRNA aspartic } \\
\text { acid methyltransferase } 1 \\
\text { (TRDMT1), mRNA }\end{array}$ & NM_004412.5 & $\begin{array}{l}\text { RNA } \\
\text { processing }\end{array}$ & 10p15.1 & & 9592134 \\
\hline 58 & PRELID3B & $\begin{array}{l}\text { Homo sapiens PRELI domain } \\
\text { containing 3B (PRELID3B), } \\
\text { transcript variant 1, mRNA }\end{array}$ & NM_016045.2 & $\begin{array}{l}\text { Signal } \\
\text { transduction }\end{array}$ & $20 q 13.32$ & & \\
\hline 59 & MRPS21 & $\begin{array}{l}\text { Homo sapiens mitochondrial } \\
\text { ribosomal protein S21 } \\
\text { (MRPS21), transcript variant 2, } \\
\text { mRNA }\end{array}$ & NM_018997.3 & Transcription & $1 q 21$ & & \\
\hline 60 & PNRC2 & $\begin{array}{l}\text { Homo sapiens proline-rich } \\
\text { nuclear receptor coactivator } 2 \\
\text { (PNRC2), mRNA }\end{array}$ & NM_017761.3 & Transcription & 1p36.11 & & \\
\hline 61 & POLR2D & $\begin{array}{l}\text { Homo sapiens polymerase } \\
\text { (RNA) II (DNA directed) } \\
\text { polypeptide D (POLR2D), } \\
\text { mRNA }\end{array}$ & NM_004805.3 & Transcription & $2 q 21$ & & \\
\hline 62 & SNHG16 & $\begin{array}{l}\text { Homo sapiens small nucleolar } \\
\text { RNA host gene } 16 \text { (non-protein } \\
\text { coding) (SNHG16), transcript } \\
\text { variant } 1 \text {, long non-coding RNA }\end{array}$ & NR_038108.1 & $\begin{array}{l}\text { Non-cording } \\
\text { RNA }\end{array}$ & ch. 17 & & \\
\hline 63 & FAM91A1 & $\begin{array}{l}\text { Homo sapiens family with } \\
\text { sequence similarity 91, member } \\
\text { A1 (FAM91A1), mRNA }\end{array}$ & NM_144963.2 & $\begin{array}{l}\text { Unknown } \\
\text { function }\end{array}$ & $8 q 24.13$ & & \\
\hline 64 & TEX9 & $\begin{array}{l}\text { Homo sapiens testis expressed } \\
9 \text { (TEX9), transcript variant } 1 \text {, } \\
\text { mRNA }\end{array}$ & NM_198524.2 & $\begin{array}{l}\text { Unknown } \\
\text { function }\end{array}$ & $15 q 21.3$ & & \\
\hline
\end{tabular}

\section{Expression profiles of subtracted genes in human ES cells}

We performed expression profile analysis of subtracted genes in human ES cells. Some subtracted genes have been reported previously, including, FXR1, NACA, TERF1, TMBIM6, WNK3, YWHAZ, PCDH15, PCDH18, PTPRF, STOM, AURKA, HSP91AA1, ORC3, SKIL, SMC3, 
ACVR2A, CD9, CDH1, DPYSL2, FANCD2, PGK1, RB1CC1, SORL1, SPEN, TFRC, UGUG, USP9X, ZNF281, IFITM1, HSPD1, ACP1, CCT2, DEK, EEF1A1, GARS, JMJD1C, NECAB1, PDK1, PLOD2, SEPHS1, SLC2A3, CD24, GPC4, NAP1L1, NPM1, HNRNPA3, HSPA8, LARP7, DPPA4, EGR1, H2AFZ, and MALAT1. Instead of the previously reported genes, we used RT-PCR to analyze the expression profiles of thirty eight genes: FASTKD1, JADE1, TMA7, ASUN, HAUS1, YTHDF3, ARL61P1, IARS, NDC1, SLC39A10, AASS, ATP5C1, AZIN1, CECR2, COPZ1, G3BP1, GPN1, EIF4A2, LRBA, LYPLA1, MYL6, NDUFS5, OTUD4, PSMD2, RASSF3, RPL14, SERINC5, SLC44A1, SSR2, UBE2H, UBE2W, UGP2, SLC35F2, CPSF6, HNRNPA3, MATR3, DPY30, and ESRG (Fig. 3).According to RT-PCR datas, human ES cells showed significantly higher expression levelsthan NP cells derived from human ES cells for the following nineteen genes: FASTK1, JADE1, ASUN, ATP5C1, CECR2, COPZ1, EIF4A2, G3PBP1, GPN1, MYL6, NDUFS5, OTUD4, PSMD2, SERINC5, SLC44A1, UGP2, CPSF6, MATR3, and DPY30. We reanalyzed expressed pattern of nineteen genes using quantitative RT-PCR. Specially, COPZ1, CPSF6, MATR3 were expressed human ES cell, not NP cells (Fig. 5A). These result suggest that three gene seem to be related proliferation or stemness of human ES cells.

\section{Expression profiles of subtracted genes in NP cells derived from human ES cells}

Furthermore, we performed expression profiling for subtracted genes of NP cells derived from ES cells. Similar to the subtracted genes of human ES cells, some subtractedgeneshave been reported in previous studies of neural development,including CASK, CCDC80, TUBA1A, CCNB2, CUL1, PSMD1, ADAM10, CD46, DAD1, DAZAP2, EIF4E, HMGCS1, MEIS1, SOX4, SOX11, STMN1, TPM1, CHMP2B, ERCC1, HPRT1, PAICS, TRA2B, CREG1, PELI1, SETD5, HNRNPA1, HNRNPA2B1, TRDMT1 and PRELID3. Excluding those twenty-ninegenes, we analyzed the expression levels of subtracted genes of NP cells derived from human ES cells during neural differentiation from human ES cells using RT-PCR,specifically CAPZA1, CCDC90B, SPTBN1, TMOD3, TRIQK, IST1, PSMA5, PSMD14, GGNBP2, ILDR2, NIPBL, PYG01, TAF8, WDR19, ALDH18A1, CBR4, EXOSC8, GBE1, NDUFS2, NIPA2, OSTC, PSMB3, RPL24, RPLP0, RPLP1, SH3BGRL, TBC1D15, UGDH, TPRKB, MRPS21, PNRC2, POLR2D, SNHG16, FAM91A1, and TEX9 (Fig. 4).Notably, NP cells derived from human ES cells showed significantly lower expressionthan human ES cells for twenty subtracted genes: CAPZA1, CCDC90B, TMOD3, TRIQK, IST1, PSMD14, GGNBP2, NIPBL, WDR19, ALDH18A1, CBR4, GBE1, PSMB3, RPLP0, TBC1D15, UGDH, TPRKB, POLR2D, SNHG16 and FAM91A1. Likewise, we re-analyzed expression level of twelve genes using quantitative RT-PCR. In Fig. 5B, TMOD was not expressed human ES cells, but it was express NP cells. These result suggest that TMOD may play a role on development in NP cells derived from human ES cells.

\section{Discussion}

NP cells endogenously develop into neural lineages and are derived from NSCs (neural stem cells) in the spinal cord, retina or cortex (Conti and Cattaneo, 2010). Like other stem cells, NSCs are capable of both self-renewal and differentiation (Goldman, 1995). However, although NSCs are good cell source for regenerative medicine, there are only few NSCs to be used broadly (Conti and Cattaneo, 2010). Many researchers have produced NSCs in vitro using human ES cells, iPS cells or SCNT-ES cells, which can be applied in regenerative medicine (Trounson and McDonald, 2015). During the differentiation and neural development of NP cells, they adopt a specific morphology called the neural rosette. Neural rosette cells can differentiate into various cell types within the neural lineage, including neurons, astrocytes and oligodendrocytes (Gaspard and Vanderhaeghen, 2010).

In this study, we identified ninety downregulated genes using SSH during NP cell differentiation derived from ES cells. Functional analysis of subtracted genes in human ES cells showed that these genes were related to metabolism, development, apoptosis, cell division, RNA processing, proliferation, transcription, cell adhesion and the immune response. Metabolism-related genes play important roles in the self-renewal and differentiation of stem cells (Westermann, 2010). Human ES cells require energy metabolism, which depends on the regulation of glycolysis (Vander Heiden et al., 2009). Stimulation of glycolysis facilitates pluripotency and supports the maintenance of stemness (Kondoh et al., 2007). Aside from the previously reported genes, we used RT-PCR to analyze the expression profiles of thirty eight genes, FASTKD1, JADE1, TMA7, ASUN, HAUS1, YTHDF3, ARL61P1, IARS, NDC1, SLC39A10, AASS, ATP5C1, AZIN1, CECR2, COPZ1, G3BP1, GPN1, EIF4A2, LRBA, LYPLA1, MYL6, NDUFS5, OTUD4, PSMD2, RASSF3, RPL14, SERINC5, SLC44A1, SSR2, UBE2H, UBE2W, UGP2, SLC35F2, CPSF6, HNRNPA3, MATR3, DPY30, and ESRG. These genes have not previously been reported to be involved in ES cell maintenance. Importantly, 19 of these 38 subtracted genes showed specifically decreased expression patterns. Below, we describe these 19 subtracted genes. FASTKD1 is a member of the FASTKD family, which is characterized by a Fas-activated serine/threonine phosphoprotein domain. Members of the FASTKD family suppress FAS- or UV-induced apoptosis (Simarro et al., 2010). JADE1 has a PHD zinc finger, which is typically involved in cell proliferation and embryogenesis (Foy et al., 2008). ASUN, also called GCT1, plays critical roles in spermatogenesis and mitotic division (Jodoin et al., 2012). ATP5C1 synthesizes ATP from ADP in mitochondria and is composed of five subunits (Itoh et al., 2004). CECR2 is a chromatin-remodeling protein involved in neurogenesis and retinal development (Dawe et al., 2011). COPZ1 is one of the secretory vesicle coat proteins and is involved in cell proliferation, apoptosis and metabolism (Shtutman et al., 2011). EIF4A2 is highly expressed in skeletal muscle cells, and its expression level is related to the cell

Page $15 / 24$ 
survival rate in NSCLC (Shaoyan et al., 2013). G3BP1 has an mRNA-stabilizing effect and regulates cancer cells, including cell growth and mortality (Winslow et al., 2013). GPN1 is a GTPase characterized by a glycine/proline/asparagine motif (Mendez-Hernandez et al., 2014). MYL6 is myosin light chain type 6 and is involved in cytoskeletal organization (Goossens et al., 2007). NDUFS5 is a member of NADH dehydrogenase family, and mutation of NDUS5 induces mitochondrial disease (luso et al., 2006). OTUD4 regulates the resistance to alkylation damage in humans (Zhao et al., 2015). PSMD2 upregulates cell proliferation, and blocking PSMD2 signaling causes accumulation of cells in G1 (Matsuyama et al., 2011). SERINC5 is expressed in most eukaryote cells and underlies the incorporation of serine into phosphatidylserine and sphingolipids (Usami et al., 2015). SLC44A1 is related to the transfer of choline into the mitochondria (Michel and Bakovic, 2009). UGP2 is UDP-glucose pyrophosphorylase 2; it catalyzes glucose transfer and is important for carbohydrate metabolism (Fuhring et al., 2013). CPSF6 is regulated by the hTERT promoter and is strongly expressed in lung adenocarcinoma (Chen et al., 2014). MART3 is an inner nuclear matrix protein and contributes to various functions including chromatin organization; DNA replication, transcription, and repair; and RNA processing and transport (Salton et al., 2010). DPY30 shows highly increased expression levels in gastric cancer cells, in which it promotes proliferation and migration (Lee et al., 2015).

In this study, we also identified sixty-four subtracted genes from NP cells derived from human ES cells. Similarly, we analyzed the functional distribution of these genes. These genes are related to metabolism, development, cell adhesion, cell division, proliferation, RNA processing, and transcription In addition, metabolism-related genes are belonged to multiple pathways, as in the results from ES cell subtraction. When ES cells differentiate, glycolysis dramatically decreases, but mitochondrial oxidative phosphorylation increases (Cho et al., 2006). Metabolic processes are important mechanisms for living cells (Cho et al., 2006; Kondoh et al., 2007; Shyh-Chang et al., 2013; Vander Heiden et al., 2009; Westermann, 2010). Neural differentiation from ES cells changed the expression of various genes, including Nestin and Pax-6 (Gaspard and Vanderhaeghen, 2010; Yap et al., 2015). In this study, sixty-four subtracted genes showed increased expression levels in NP cells derived from human ES cells. Setting aside the already known genes, we analyzed the thirty-five upregulated genes, CAPZA1, CCDC90B, SPTBN1, TMOD3, TRIQK, IST1, PSMA5, PSMD14, GGNBP2, ILDR2, NIPBL, PYG01, TAF8, WDR19, ALDH18A1, CBR4, EXOSC8, GBE1, NDUFS2, NIPA2, OSTC, PSMB3, RPL24, RPLP0, RPLP1, SH3BGRL, TBC1D15, UGDH, TPRKB, MRPS21, PNRC2, POLR2D, SNHG16, FAM91A1, and TEX9, that were not previously associated with neural differentiation. Among them, twenty subtracted genes showed gradually increased expression during neural development. Below, we describe the subtracted genes showing higher expression in NP cells derived from ES cells than in human ES cells. CAPZA1 is upregulated in patients with gastric cancer and is a good marker for early stages of gastric cancer (Lee et al., 2013). CCDC90B is a mitochondrial integral membrane protein and is related to ES cell differentiation (Brandenberger et al., 2004). TMOD3 binds actin filaments, and the TMOD3-null mutant is embryonic lethal in mice (Sui et al., 2014). TRIQK is a membrane protein in the endoplasmic reticulum and is involved in regulating embryogenesis (Onuma et al., 2008). IST1 plays essential roles in cytokinesis during mammalian cell division (Agromayor et al., 2009). PSMD14 are two proteasomal subunits that contribute to the cleavage of ubiquitinated peptides. The lack of PSMD14 promotes cell cycle arrest and cellular senescence (Brandenberger et al., 2004). GGNBP2 is a tumor suppressor gene and is used for novel diagnosis and therapeutic applications in breast cancers (Lan et al., 2016). NIPBL is a cohesion-loading factor that is important in the G1/S transition (Zuin et al., 2014). WDR19 is overexpressed in prostate cancer and may be a new cancer biomarker (Lin et al., 2008). ALDH18A1 is mainly involved in an unusual metabolic pathway and encodes the protein P5CS, which is important for the first step in proline and ornithine biosynthesis (Bicknell et al., 2008). CBR4 belongs to the short-chain dehydrogenase/reductase superfamily, whose members play roles in steroid metabolism (Endo et al., 2008) GBE1 is a major factor in glycogen storage, and deficiency in this gene leads to genetic disorders such as glycogen storage disease type IV (Said et al., 2016). PSMB3 is another type of proteasomal subunit and is involved in genome stabilization (Gemoll et al., 2013). RPLP0 is a ribosomal protein that interacts with rRNA and is involved with translation in eukaryotic cells (Artero-Castro et al., 2011). TBC1D15 shows oncoprotein activity and promotes self-renewal in tumor-initiating stem-like cells (Feldman et al., 2013). UGDH shows strongly increased expression in breast cancer cells, in which it promotes cell proliferation (Hwang et al., 2008). TPRKB, also called CGI-121, potentially inhibits the binding of PRPK to p53 (Miyoshi et al., 2003). POLR2D is type of RNA polymerase II subunit that is related to transcription regulation (Khazak et al., 1998). SNHG16 affects lipid metabolism and has an oncogenic effect in colorectal cancer (Christensen et al., 2016). The functions of FAM91A1 are unknown.

\section{Conclusions}

In summary, we identified genes that are differentially expressed during neural differentiation from human ES cells. We used SSH to identify and characterize genes in NP cells showing either upregulated or downregulated expression in comparison to the human ES cells from which the NP cells were derived. Analysis of the subtracted genes showed that 90 genes were downregulated and 64 genes were upregulated in NP cells compared with human ES cells. Several genes (subtraction of hES cells; 52 genes, subtraction of NP cells; 29 genes) have already been reported in neural development from human ES cells. Aside from those known genes, the remaining subtracted genes might be related to neurogenesis. Many of the subtracted genes in this study were involved in metabolism (subtraction of human 
ES cells; $37 \%$, subtraction of NP cells; $30 \%$ ) or development (subtraction of human ES cells; $18 \%$, subtraction of NP cells; $26 \%$ ). This study suggests that the subtracted genes (COPZ1, CPSF6, MART3 and TMOD3) will provide insight into their specific function in differentiation of NP cells from human ES cells.

\section{Declarations}

\section{Author Contributions}

JK Yoo and JK Kim designed the study. JK Yoo, HM Noh and SJ Choi differentiated NP and performed in vitro experiments. JK Yoo, HM Noh, JH Kim and JK Kim analyzed the data. SJ Choi created figures for the results. JK Yoo, SH Lim, SJ Choi and JK Kim wrote the manuscript with inputs from all the authors and reviewed the manuscript. All authors read and approved the final manuscript.

\section{Acknowledgments}

This research wassupported by Basic Science Research Program, Mid-career Research Program and the Bio \& Medical Technology Development Program through the National Research Foundation of Korea (NRF) grant funded by Korea government (MSIP) (No. 2016R1C1B1013723, No. 2016R1A2B4008291) of the Republic of Korea.

Conflict of interest:The authors have no conflicts of interest with this research.

Ethical approval: This article does not contain any studies with human participants or animals performed by any of the authors

\section{References}

1. Agromayor, M., J.G. Carlton, J.P. Phelan, D.R. Matthews, L.M. Carlin, S. Ameer-Beg, K. Bowers, and J. Martin-Serrano. 2009. Essential role of hIST1 in cytokinesis. Mol Biol Cell. 20:1374-1387.

2. Artero-Castro, A., J. Castellvi, A. Garcia, J. Hernandez, S. Ramon y Cajal, and M.E. Lleonart. 2011. Expression of the ribosomal proteins Rplp0, Rplp1, and Rplp2 in gynecologic tumors. Hum Pathol. 42:194-203.

3. Bicknell, L.S., J. Pitt, S. Aftimos, R. Ramadas, M.A. Maw, and S.P. Robertson. 2008. A missense mutation in ALDH18A1, encoding Delta1-pyrroline-5-carboxylate synthase (P5CS), causes an autosomal recessive neurocutaneous syndrome. Eur J Hum Genet. 16:1176-1186.

4. Brandenberger, R., H. Wei, S. Zhang, S. Lei, J. Murage, G.J. Fisk, Y. Li, C. Xu, R. Fang, K. Guegler, M.S. Rao, R. Mandalam, J. Lebkowski, and L.W. Stanton. 2004. Transcriptome characterization elucidates signaling networks that control human ES cell growth and differentiation. Nat Biotechnol. 22:707-716.

5. Carpenter, M.K., X. Cui, Z.Y. Hu, J. Jackson, S. Sherman, A. Seiger, and L.U. Wahlberg. 1999. In vitro expansion of a multipotent population of human neural progenitor cells. Exp Neurol. 158:265-278.

6. Chen, W., L. Qin, S. Wang, M. Li, D. Shi, Y. Tian, J. Wang, L. Fu, Z. Li, W. Guo, W. Yu, Y. Yuan, T. Kang, W. Huang, and W. Deng. 2014. CPSF4 activates telomerase reverse transcriptase and predicts poor prognosis in human lung adenocarcinomas. Mol Oncol. 8:704716.

7. Cho, Y.M., S. Kwon, Y.K. Pak, H.W. Seol, Y.M. Choi, D.J. Park, K.S. Park, and H.K. Lee. 2006. Dynamic changes in mitochondrial biogenesis and antioxidant enzymes during the spontaneous differentiation of human embryonic stem cells. Biochem Biophys Res Commun. 348:1472-1478.

8. Christensen, L.L., K. True, M.P. Hamilton, M.M. Nielsen, N.D. Damas, C.K. Damgaard, H. Ongen, E. Dermitzakis, J.B. Bramsen, J.S. Pedersen, A.H. Lund, S. Vang, K. Stribolt, M.R. Madsen, S. Laurberg, S.E. McGuire, T.F. Orntoft, and C.L. Andersen. 2016. SNHG16 is regulated by the Wnt pathway in colorectal cancer and affects genes involved in lipid metabolism. Mol Oncol.

9. Conti, L., and E. Cattaneo. 2010. Neural stem cell systems: physiological players or in vitro entities? Nat Rev Neurosci. 11:176-187.

10. Dawe, C.E., M.K. Kooistra, N.A. Fairbridge, A.C. Pisio, and H.E. McDermid. 2011. Role of chromatin remodeling gene Cecr2 in neurulation and inner ear development. Dev Dyn. 240:372-383.

11. de Wert, G., and C. Mummery. 2003. Human embryonic stem cells: research, ethics and policy. Hum Reprod. 18:672-682.

12. Endo, S., T. Matsunaga, Y. Kitade, S. Ohno, K. Tajima, O. El-Kabbani, and A. Hara. 2008. Human carbonyl reductase 4 is a mitochondrial NADPH-dependent quinone reductase. Biochem Biophys Res Commun. 377:1326-1330. 
13. Evans, P.M., and C. Liu. 2008. Roles of Krupel-like factor 4 in normal homeostasis, cancer and stem cells. Acta Biochim Biophys Sin (Shanghai). 40:554-564.

14. Feldman, D.E., C. Chen, V. Punj, and K. Machida. 2013. The TBC1D15 oncoprotein controls stem cell self-renewal through destabilization of the Numb-p53 complex. PLoS One. 8:e57312.

15. Foy, R.L., I.Y. Song, V.C. Chitalia, H.T. Cohen, N. Saksouk, C. Cayrou, C. Vaziri, J. Cote, and M.V. Panchenko. 2008. Role of Jade-1 in the histone acetyltransferase (HAT) HBO1 complex. J Biol Chem. 283:28817-28826.

16. Fuhring, J., S. Damerow, R. Fedorov, J. Schneider, A.K. Munster-Kuhnel, and R. Gerardy-Schahn. 2013. Octamerization is essential for enzymatic function of human UDP-glucose pyrophosphorylase. Glycobiology. 23:426-437.

17. Gaspard, N., and P. Vanderhaeghen. 2010. Mechanisms of neural specification from embryonic stem cells. Curr Opin Neurobiol. 20:37-43.

18. Gemoll, T., J.K. Habermann, S. Becker, S. Szymczak, M.B. Upender, H.P. Bruch, U. Hellman, T. Ried, G. Auer, H. Jornvall, and U.J. Roblick. 2013. Chromosomal aneuploidy affects the global proteome equilibrium of colorectal cancer cells. Anal Cell Pathol (Amst). 36:149-161.

19. Goldman, S.A. 1995. Neuronal precursor cells and neurogenesis in the adult forebrain. Neuroscientist. 1:338-350.

20. Goossens, K., A. Van Soom, M. Van Poucke, L. Vandaele, J. Vandesompele, A. Van Zeveren, and L.J. Peelman. 2007. Identification and expression analysis of genes associated with bovine blastocyst formation. BMC Dev Biol. 7:64.

21. Hwang, E.Y., J.W. Huh, M.M. Choi, S.Y. Choi, H.N. Hong, and S.W. Cho. 2008. Inhibitory effects of gallic acid and quercetin on UDPglucose dehydrogenase activity. FEBS Lett. 582:3793-3797.

22. Itoh, H., A. Takahashi, K. Adachi, H. Noji, R. Yasuda, M. Yoshida, and K. Kinosita. 2004. Mechanically driven ATP synthesis by F1ATPase. Nature. 427:465-468.

23. Iuso, A., S. Scacco, C. Piccoli, F. Bellomo, V. Petruzzella, R. Trentadue, M. Minuto, M. Ripoli, N. Capitanio, M. Zeviani, and S. Papa. 2006. Dysfunctions of cellular oxidative metabolism in patients with mutations in the NDUFS1 and NDUFS4 genes of complex I. $J$ Biol Chem. 281:10374-10380.

24. Jodoin, J.N., M. Shboul, P. Sitaram, H. Zein-Sabatto, B. Reversade, E. Lee, and L.A. Lee. 2012. Human Asunder promotes dynein recruitment and centrosomal tethering to the nucleus at mitotic entry. Mol Biol Cell. 23:4713-4724.

25. Jung, H.M., S.J. Choi, and J.K. Kim. 2009. Expression profiles of SV40-immortalization-associated genes upregulated in various human cancers. J Cell Biochem. 106:703-713.

26. Khazak, V., J. Estojak, H. Cho, J. Majors, G. Sonoda, J.R. Testa, and E.A. Golemis. 1998. Analysis of the interaction of the novel RNA polymerase II (pol II) subunit hsRPB4 with its partner hsRPB7 and with pol II. Mol Cell Biol. 18:1935-1945.

27. Kim, J., S.H. Moon, S.H. Lee, D.R. Lee, G.Y. Koh, and H.M. Chung. 2007. Effective isolation and culture of endothelial cells in embryoid body differentiated from human embryonic stem cells. Stem Cells Dev. 16:269-280.

28. Kim, S., J.Y. Hong, S.Y. Joo, J.H. Kim, S.Y. Moon, H.S. Yoon, D.H. Kim, H.M. Chung, and S.-J. Choi. 2004. Derivation of Neural Precursor Cells from Human Embryonic Stem Cells. Reprod Dev Biol. 28:247-252.

29. Kondoh, H., M.E. Lleonart, Y. Nakashima, M. Yokode, M. Tanaka, D. Bernard, J. Gil, and D. Beach. 2007. A high glycolytic flux supports the proliferative potential of murine embryonic stem cells. Antioxid Redox Signal. 9:293-299.

30. Lan, Z.J., Y. Hu, S. Zhang, X. Li, H. Zhou, J. Ding, C.M. Klinge, B.N. Radde, A.J. Cooney, J. Zhang, and Z. Lei. 2016. GGNBP2 acts as a tumor suppressor by inhibiting estrogen receptor alpha activity in breast cancer cells. Breast Cancer Res Treat. 158:263-276.

31. Lee, Y.J., M.E. Han, S.J. Baek, S.Y. Kim, and S.O. Oh. 2015. Roles of DPY30 in the Proliferation and Motility of Gastric Cancer Cells. PLoS One. 10:e0131863.

32. Lee, Y.J., S.H. Jeong, S.C. Hong, B.I. Cho, W.S. Ha, S.T. Park, S.K. Choi, E.J. Jung, Y.T. Ju, C.Y. Jeong, J.W. Kim, C.W. Lee, J. Yoo, and G.H. Ko. 2013. Prognostic value of CAPZA1 overexpression in gastric cancer. Int J Oncol. 42:1569-1577.

33. Lin, B., A.G. Utleg, K. Gravdal, J.T. White, O.J. Halvorsen, W. Lu, L.D. True, R. Vessella, P.H. Lange, P.S. Nelson, L. Hood, K.H. Kalland, and L.A. Akslen. 2008. WDR19 expression is increased in prostate cancer compared with normal cells, but low-intensity expression in cancers is associated with shorter time to biochemical failures and local recurrence. Clin Cancer Res. 14:1397-1406.

34. Matsuyama, Y., M. Suzuki, C. Arima, Q.M. Huang, S. Tomida, T. Takeuchi, R. Sugiyama, Y. Itoh, Y. Yatabe, H. Goto, and T. Takahashi. 2011. Proteasomal non-catalytic subunit PSMD2 as a potential therapeutic target in association with various clinicopathologic features in lung adenocarcinomas. Mol Carcinog. 50:301-309. 
35. Mendez-Hernandez, L.E., A.E. Perez-Mejia, B. Lara-Chacon, A.A. Barbosa-Camacho, S.G. Pena-Gomez, M. Martinez-Sanchez, A.Y. Robledo-Rivera, R. Sanchez-Olea, and M.R. Calera. 2014. Gpn1 and Gpn3 associate tightly and their protein levels are mutually dependent in mammalian cells. FEBS Lett. 588:3823-3829.

36. Michel, V., and M. Bakovic. 2009. The solute carrier 44A1 is a mitochondrial protein and mediates choline transport. FASEB J. 23:2749-2758.

37. Miyoshi, A., K. Kito, T. Aramoto, Y. Abe, N. Kobayashi, and N. Ueda. 2003. Identification of CGI-121, a novel PRPK (p53-related protein kinase)-binding protein. Biochem Biophys Res Commun. 303:399-405.

38. Noh, H.M., S.-J. Choi, S. Kim, K.-S. Kim, and J.K. Kim. 2007. Differential Expression of TPX2 upon Differentiation of Human Embryonic Stem Cells. Reprod Dev Biol. 31:221-226.

39. Onuma, Y., A. Watanabe, H. Aburatani, M. Asashima, and M. Whitman. 2008. TRIQK, a novel family of small proteins localized to the endoplasmic reticulum membrane, is conserved across vertebrates. Zoolog Sci. 25:706-713.

40. Ramalho-Santos, M., S. Yoon, Y. Matsuzaki, R.C. Mulligan, and D.A. Melton. 2002. "Stemness": transcriptional profiling of embryonic and adult stem cells. Science. 298:597-600.

41. Rippon, H.J., and A.E. Bishop. 2004. Embryonic stem cells. Cell Prolif. 37:23-34.

42. Said, S.M., M.I. Murphree, T. Mounajjed, M. El-Youssef, and L. Zhang. 2016. A novel GBE1 gene variant in a child with glycogen storage disease type IV. Hum Pathol. 54:152-156.

43. Salton, M., Y. Lerenthal, S.Y. Wang, D.J. Chen, and Y. Shiloh. 2010. Involvement of Matrin 3 and SFPQ/NONO in the DNA damage response. Cell Cycle. 9:1568-1576.

44. Shaoyan, X., Y. Juanjuan, T. Yalan, H. Ping, L. Jianzhong, and W. Qinian. 2013. Downregulation of EIF4A2 in non-small-cell lung cancer associates with poor prognosis. Clin Lung Cancer. 14:658-665.

45. Shtutman, M., M. Baig, E. Levina, G. Hurteau, C.U. Lim, E. Broude, M. Nikiforov, T.T. Harkins, C.S. Carmack, Y. Ding, F. Wieland, R. Buttyan, and I.B. Roninson. 2011. Tumor-specific silencing of COPZ2 gene encoding coatomer protein complex subunit zeta 2 renders tumor cells dependent on its paralogous gene COPZ1. Proc Natl Acad Sci U S A. 108:12449-12454.

46. Shyh-Chang, N., G.Q. Daley, and L.C. Cantley. 2013. Stem cell metabolism in tissue development and aging. Development. 140:25352547.

47. Simarro, M., A. Gimenez-Cassina, N. Kedersha, J.B. Lazaro, G.O. Adelmant, J.A. Marto, K. Rhee, S. Tisdale, N. Danial, C. Benarafa, A. Orduna, and P. Anderson. 2010. Fast kinase domain-containing protein 3 is a mitochondrial protein essential for cellular respiration. Biochem Biophys Res Commun. 401:440-446.

48. Sui, Z., R.B. Nowak, A. Bacconi, N.E. Kim, H. Liu, J. Li, A. Wickrema, X.L. An, and V.M. Fowler. 2014. Tropomodulin3-null mice are embryonic lethal with anemia due to impaired erythroid terminal differentiation in the fetal liver. Blood. 123:758-767.

49. Tachibana, M., P. Amato, M. Sparman, N.M. Gutierrez, R. Tippner-Hedges, H. Ma, E. Kang, A. Fulati, H.S. Lee, H. Sritanaudomchai, K. Masterson, J. Larson, D. Eaton, K. Sadler-Fredd, D. Battaglia, D. Lee, D. Wu, J. Jensen, P. Patton, S. Gokhale, R.L. Stouffer, D. Wolf, and S. Mitalipov. 2013. Human embryonic stem cells derived by somatic cell nuclear transfer. Cell. 153:1228-1238.

50. Takahashi, K., K. Tanabe, M. Ohnuki, M. Narita, T. Ichisaka, K. Tomoda, and S. Yamanaka. 2007. Induction of pluripotent stem cells from adult human fibroblasts by defined factors. Cell. 131:861-872.

51. Trounson, A., and C. McDonald. 2015. Stem Cell Therapies in Clinical Trials: Progress and Challenges. Cell Stem Cell. 17:11-22.

52. Usami, Y., Y. Wu, and H.G. Gottlinger. 2015. SERINC3 and SERINC5 restrict HIV-1 infectivity and are counteracted by Nef. Nature. 526:218-223.

53. Vander Heiden, M.G., L.C. Cantley, and C.B. Thompson. 2009. Understanding the Warburg effect: the metabolic requirements of cell proliferation. Science. 324:1029-1033.

54. Westermann, B. 2010. Mitochondrial fusion and fission in cell life and death. Nat Rev Mol Cell Biol. 11:872-884.

55. Wilcox, J.T., K. Satkunendrarajah, J.A. Zuccato, F. Nassiri, and M.G. Fehlings. 2014. Neural precursor cell transplantation enhances functional recovery and reduces astrogliosis in bilateral compressive/contusive cervical spinal cord injury. Stem Cells Trans/ Med. 3:1148-1159.

56. Winslow, S., K. Leandersson, and C. Larsson. 2013. Regulation of PMP22 mRNA by G3BP1 affects cell proliferation in breast cancer cells. Mol Cancer. 12:156.

57. Yap, M.S., K.R. Nathan, Y. Yeo, L.W. Lim, C.L. Poh, M. Richards, W.L. Lim, I. Othman, and B.C. Heng. 2015. Neural Differentiation of Human Pluripotent Stem Cells for Nontherapeutic Applications: Toxicology, Pharmacology, and In Vitro Disease Modeling. Stem 
Cells Int. 2015:105172.

58. Yoo, J.K., J.J. Lim, J.J. Ko, D.R. Lee, and J.K. Kim. 2010. Expression profile of genes identified in human spermatogonial stem celllike cells using suppression subtractive hybridization. J Cell Biochem. 110:752-762.

59. Zacharias, D.G., T.J. Nelson, P.S. Mueller, and C.C. Hook. 2011. The science and ethics of induced pluripotency: what will become of embryonic stem cells? Mayo Clin Proc. 86:634-640.

60. Zhao, Y., M.C. Majid, J.M. Soll, J.R. Brickner, S. Dango, and N. Mosammaparast. 2015. Noncanonical regulation of alkylation damage resistance by the OTUD4 deubiquitinase. EMBO J. 34:1687-1703.

61. Zuin, J., V. Franke, W.F. van ljcken, A. van der Sloot, I.D. Krantz, M.I. van der Reijden, R. Nakato, B. Lenhard, and K.S. Wendt. 2014. A cohesin-independent role for NIPBL at promoters provides insights in CdLS. PLoS Genet. 10:e1004153.

\section{Figures}

A

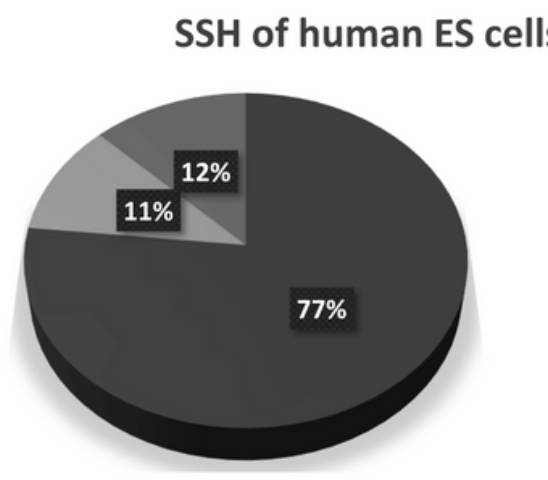

\section{B}

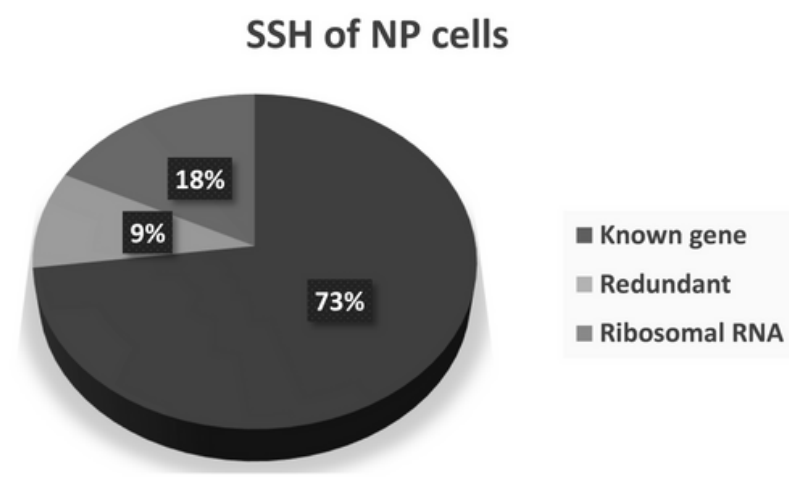

\section{Figure 1}

Pie chart showing the categories into which the subtracted clones are distributed. (A)Subtracted clones in human ES cells. (B) Subtracted clones in NP cells derived from human ES cells. 

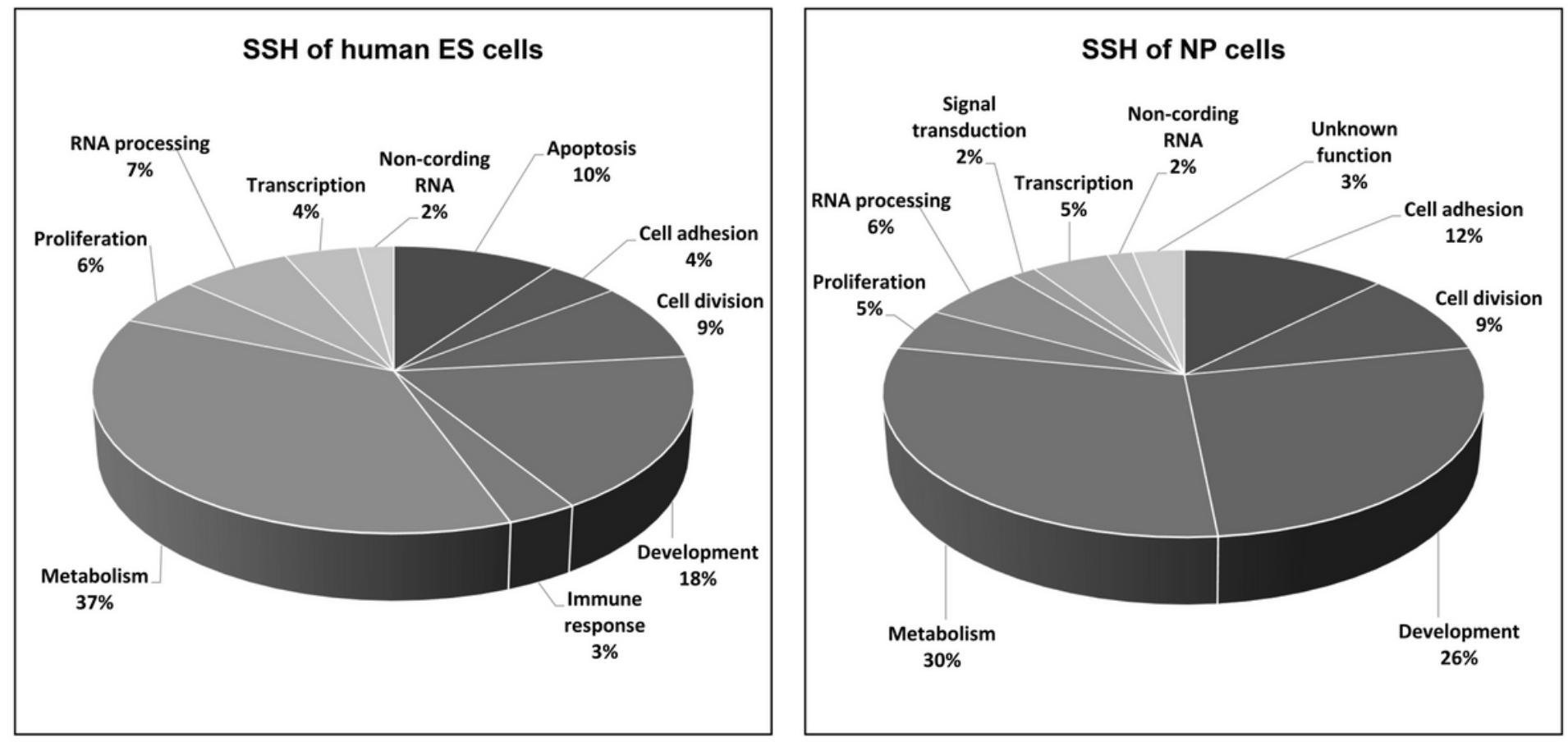

\section{Figure 2}

Pie charts showing the functional classification of subtracted genes. The functions of the subtracted genes were determined using the NCBI database. (A) Subtracted genes in human ES cells (92 of the subtracted genes showed lower expression levels in NP cells derived from human ES cells than in human ES cells). (B) Subtracted genes in NP cells derived from human ES cells (64 of the subtracted genes showed higher expression levels in NP cells). 


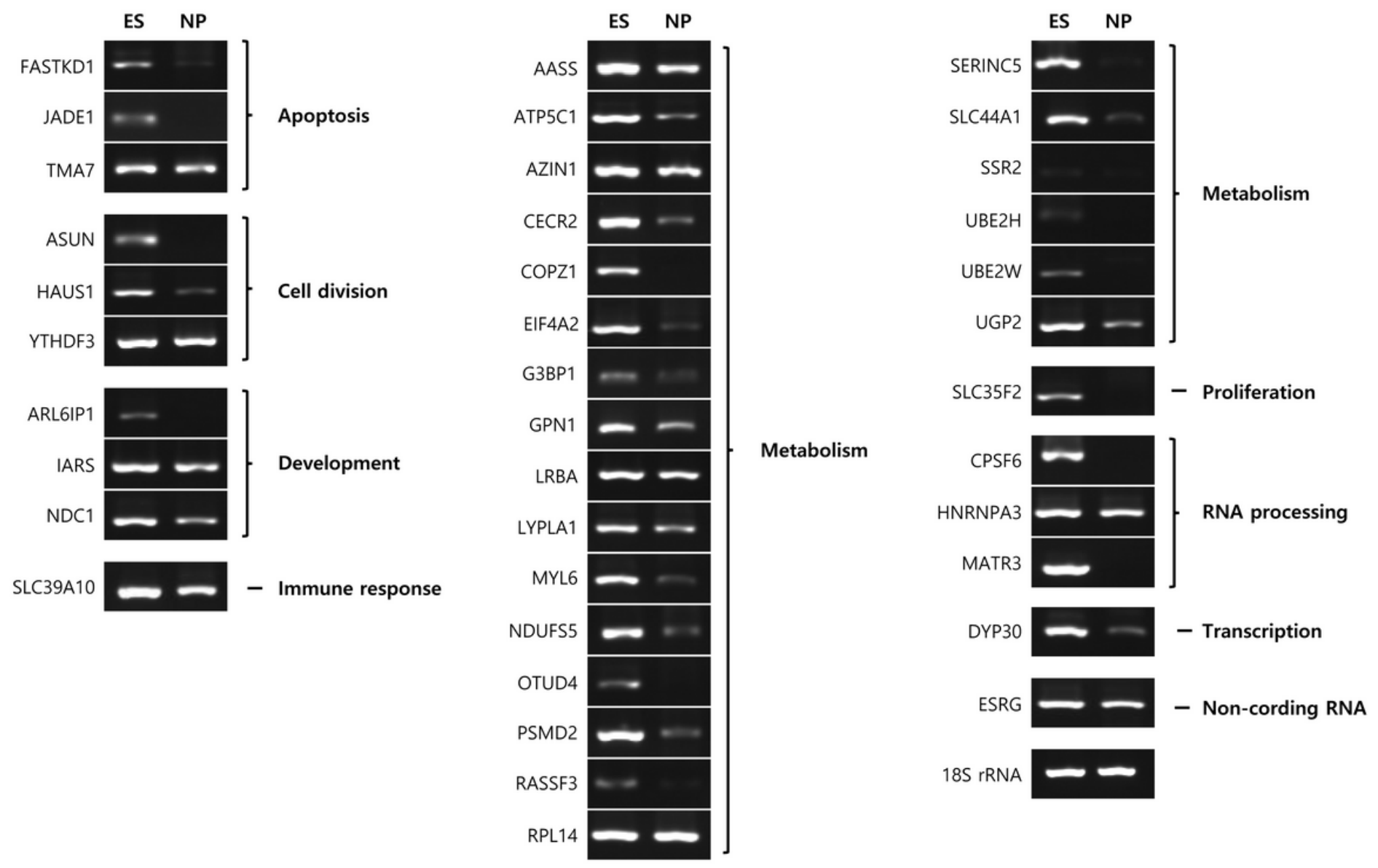

Figure 3

Expression profiles of subtracted genes from human ES cells. Subtracted genes of human ES cells showing downregulated expression during neural development compared with human ES cells. The expression profiles were obtained from three independent RT-PCR amplifications. Lane 1: human ES cells. Lane 2: NP cells derived from human ES cells. 

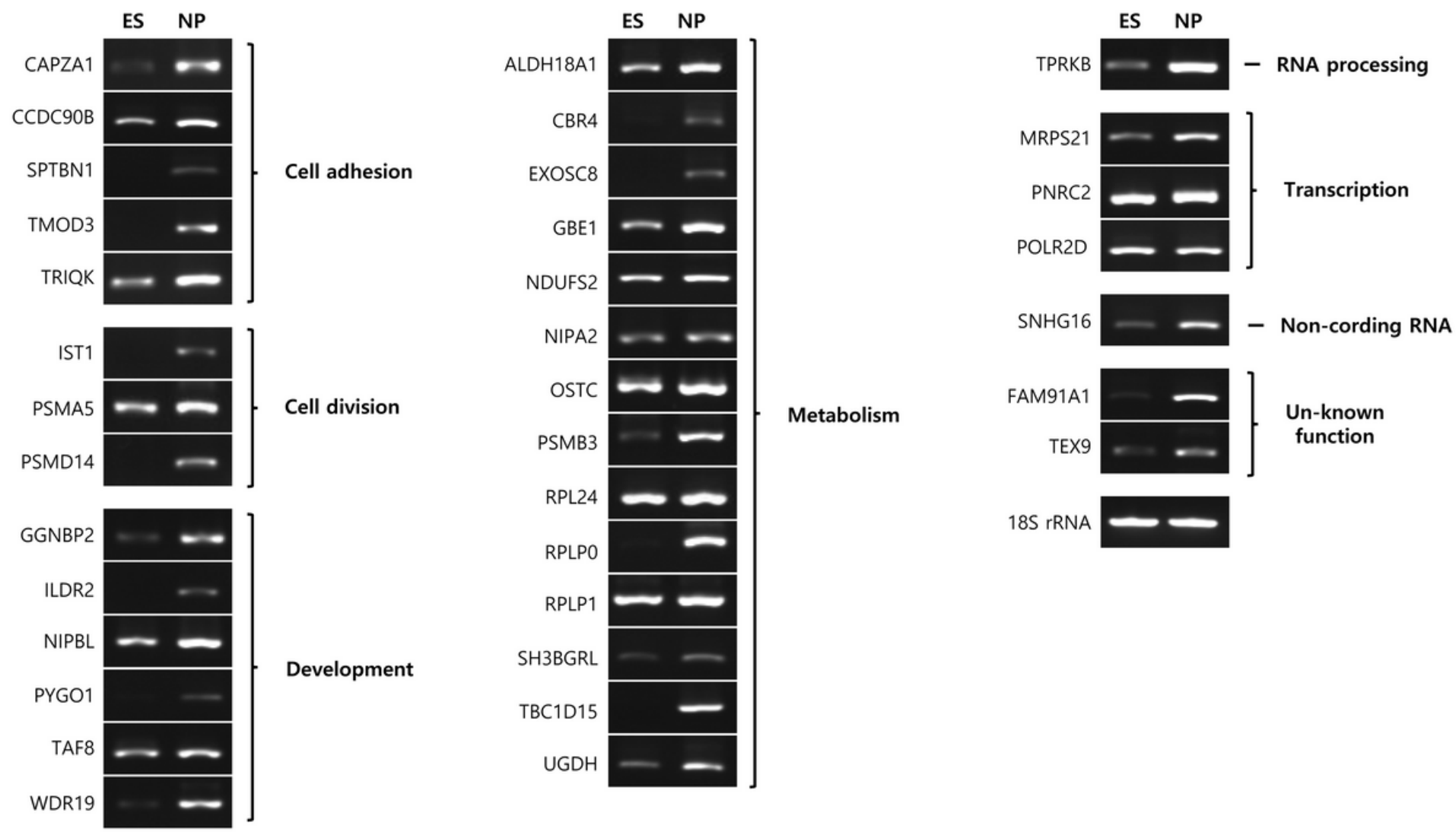

Figure 4

Expression profiles of subtracted genes from NP cells derived from human ES cells. Subtracted genes of NP cells showed upregulated expression levels, and expression profile data were obtained from three independent experiments using RT-PCR. Lane 1: human ES cells. Lane 2: NP cells derived from human ES cells. 
A

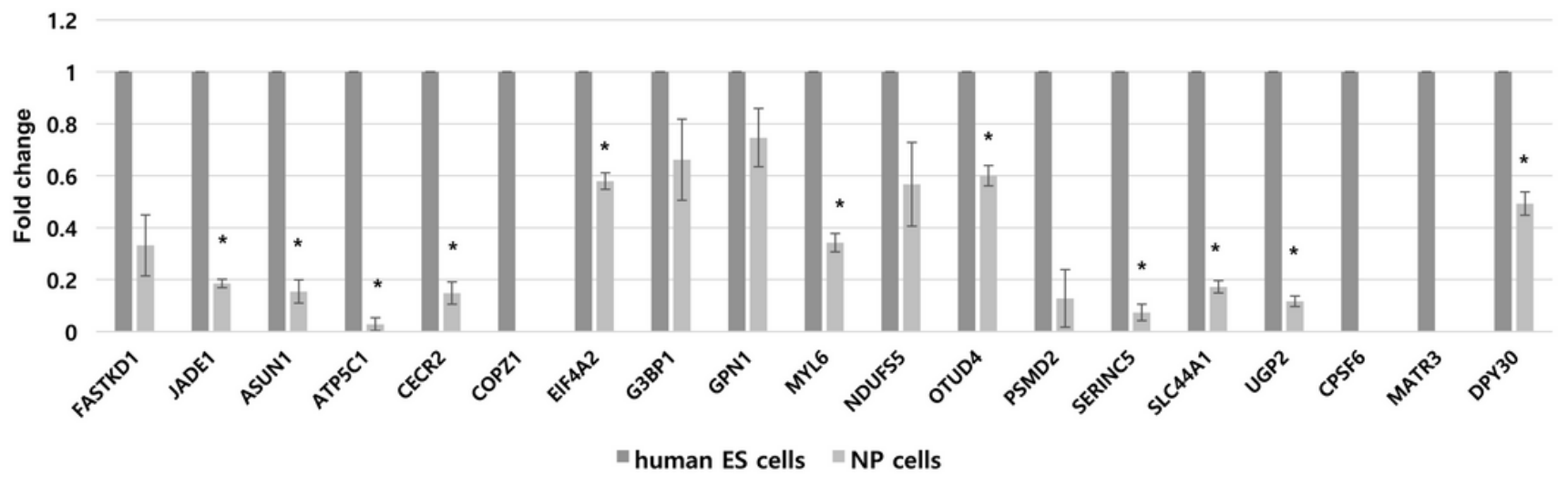

B

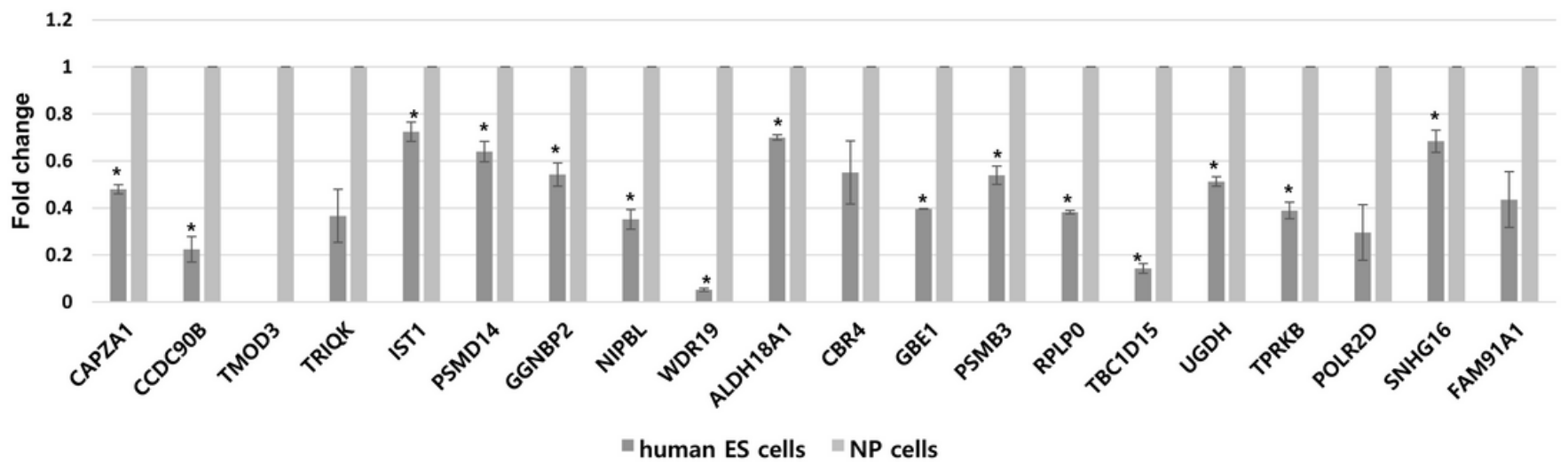

Figure 5

Re-analyzed expressing pattern of subtracted genes using quantitative RT-PCR. (A) Expression profiles of human ES cell specific genes

(B) Expression profiles of NP cell specific genes. The data represent the average of three independent experiment and are shown as the mean \pm S.E.M.; $* \mathrm{P}<0.05$

\section{Supplementary Files}

This is a list of supplementary files associated with this preprint. Click to download.

- SupplementalmaterialYOOJK.docx 